\title{
Final Devoicing and Voicing Assimilation in Dutch Derivation and Cliticization ${ }^{1}$
}

\author{
Janet Grijzenhout \& Martin Krämer \\ Heinrich-Heine-Universität Düsseldorf
}

\section{Introduction}

In derivational frameworks, final devoicing and voicing assimilation have always been regarded as evidence for rule ordering in Dutch (e.g., Berendsen 1983, Berendsen et al 1984, Zonneveld 1983). In more recent constraint-based approaches, lexical and postlexical levels have been assumed to account for some Dutch voicing phenomena (Booij 1996), and other linguists propose context-specific faithfulness constraints for a few cases of final devoicing and voicing assimilation (e.g. Lombardi 1995, 1996). A unified analysis of all phenomena related to final devoicing and/or voicing assimilation in Dutch has not been proposed yet. In this paper, we will first point out the various problems rule-based approaches encounter when all relevant facts are taken into consideration. We will then suggest an analysis that uses the Correspondence version of Optimality Theory (McCarthy \& Prince 1995) and that does not assume different levels, nor Output-Output constraints (Benua 1995), nor a device such as "Sympathy" (McCarthy 1998).

Our analysis is based on ideas presented by Booij (1995) and Selkirk (1995) who both suggest that suffixes may differ in their prosodic structure. Some suffixes do not form a Prosodic Word of their own, whereas others do. We argue that clitics in Dutch differ from suffixes in that they are directly adjoined to a Phonological Phrase. Because the prosodic structure is distinct, we expect to find differences regarding syllabification (and, hence, syllable-final devoicing) between the two kinds of suffixes and clitics. We will show that this is in fact the case. We will furthermore demonstrate that prosodic structure is also relevant to voicing assimilation. More specifically, it will be shown that it is more important to preserve the underlying voicing specification of a plosive in initial position of a Prosodic Word than to preserve voicing of a plosive that is not initial in a Prosodic Word. We will develop an analysis with (i) Alignment constraints which say that the edge of certain morphological categories should be aligned with the corresponding edge of a Prosodic Word and (ii) Identity constraints which say that the

\footnotetext{
${ }^{1}$ This is an extended version of talks presented at the SFB-Colloquium on Wordstress, 8 May 1998 in Düsseldorf, the $6^{\text {th }}$ Manchester Phonology Meeting, 23 May 1998 in Manchester, and the International Conference of the SFB 282 'Theory of the Lexicon', 18 August 1998 in Wuppertal. We would like to thank the participants of these meetings for helpful comments. Thanks are also due to Luba Butska, Birgit Gerlach, Heather Goad, and Barbara Stiebels.
} 
voicing specification of a segment in onset position of a Prosodic Word or a syllable should be identical to its input specification.

The structure of this paper is as follows. In section 2, we illustrate the phenomenon of final devoicing and we show how devoicing may be made 'invisible' by voicing assimilation in certain derivations and in compounds. We will point out some problems that rule-based derivational accounts encounter with respect to (i) the order of affixation, (ii) progressive voicing assimilation in the case of inflectional endings, and (iii) devoicing of stem-final consonants before clitics. In section 3, we present our constraint-based analysis of the different behaviour regarding syllabification and final devoicing of stem-final obstruents before two groups of native suffixes. In section 4, we first discuss Lombardi's (1995, 1996) OT-account of progressive and regressive voicing assimilation in Dutch and we will then modify her analysis so that it explains data that are problematic for her account. In section 5, we present an analysis of devoicing before clitics. Section 6 summarises the discussion.

\section{Final devoicing and affixation}

In Dutch, voicing is distinctive for obstruents. In some environments, this distinction is neutralised. For instance, all obstruents are voiceless in word-final position. This is illustrated by the examples below, where the voiced plosive /d/ in (1a) and the voiced fricative /z/ in (1c) are realised as voiceless obstruents, i.e. [t] and [s], respectively, in word-final position. The data in the second column in $(1 \mathrm{~b}, \mathrm{~d})$ illustrate that there is no intervocalic voicing of obstruents in Dutch:, 3

Final devoicing:
a. $/ \mathrm{pad} / \rightarrow$ [pat]
$/$ pad $/+$ on $\rightarrow$ [padən]
'toad', toads'
b. /lat/ $\rightarrow$ [lat $]$
/lat/ + on $\rightarrow$ [latən]
'lath', 'laths'
c. $/ \mathrm{pu}: \mathrm{z} / \rightarrow$ [pu:s]
/pu:z/ + on $\rightarrow$ [pu:zən]
'cat', cats'
d. /vos/ $\rightarrow$ [vos]
/vos/ + ən $\rightarrow$ [vosən]
'fox', 'foxes'

Whether the underlying voicing specification of a stem-final obstruent surfaces or not depends on its position within the syllable and on the following suffix. Before some

\footnotetext{
${ }^{2}$ All data in this paper are from Berendsen (1983), Booij (1995), and from one of the authors who is a native speaker of Dutch. The phonetic forms in Booij (1995) differ from the intuitions of the author in that Janet Grijzenhout does not have an underlying voiced velar fricative. In contrast to Booij (1995), we will use a length mark ':' after tense vowels, even though we note that there is no consensus in the literature concerning the length of tense vowels in Dutch.

${ }^{3}$ In Dutch, syllables with a short (lax) vowel are closed. In the examples in $(1 \mathrm{a}, \mathrm{b}, \mathrm{d})$, the intervocalic obstruent is usually assumed to be ambisyllabic, but this is not a phonetic phenomenon and these obstruents do not have a longer duration than obstruents following long (tense) vowels (see Hulst 1985).
} 
vowel-initial suffixes, a stem-final obstruent is realised in syllable-onset position with its underlying voicing specification intact. Before other vowel-initial suffixes and in compounds, a stem-final obstruent is syllable-final and voiceless. In the next section, we will demonstrate that stem-final obstruents in Dutch behave differently in derivation, compounding, and cliticization.

\subsection{Devoicing and derivation}

Stem-final obstruents that are underlyingly specified as voiced retain their voicing specification before some vowel-initial suffixes (see 1a,c, 2a-c). They are voiceless before other suffixes (see 3a,b), in compounds (see 4a,b), and before clitics (see 5a,b). In a derivational rule-based approach, it is inferred that final devoicing takes place after suffixation of the former suffixes and before suffixation of the latter suffixes, before compounding, and before cliticization (Berendsen 1983, Berendsen et al 1984, Zonneveld 1983). ${ }^{4}$
a. $/ \mathrm{ro}: \mathrm{d} / \mathrm{A}+-\mathrm{er}_{\mathrm{A}}$
$\rightarrow$ ['ro:.dər]
'red' $\rightarrow$ 'redder'
b. $/ x e: v / \mathrm{V}+-\mathrm{er}_{\mathrm{N}}$
$\rightarrow$ ['xe:.vor]
'give' $\rightarrow$ 'giver'
c. $/ \mathrm{d} o n z /{ }_{\mathrm{N}}+-\mathrm{ig}_{\mathrm{A}}$
$\rightarrow$ ['don.zəx]
'down' $\rightarrow$ 'fluffy'
a. $/$ xoud $/ \mathrm{N} \rightarrow$ /xout/ + -achtig ${ }_{\mathrm{A}} \rightarrow$ ['xout.,ax.təx]
'gold' $\rightarrow$ 'gold-like'
b. /di:v/N $\rightarrow$ /di:f/ + -achtig ${ }_{\mathrm{A}} \rightarrow$ ['di:f.,ax.tox
'thief' $\rightarrow$ 'thievish'
a. $/$ xəud $/{ }_{N} \rightarrow$ /xəut/ + ader $_{\mathrm{N}} \rightarrow$ ['xəut.,a:.dər]
'gold' $\rightarrow$ 'gold-vein'
b. /le:v/v $\rightarrow$ /le:f/ + eenheid $\mathrm{N}_{\mathrm{N}} \rightarrow$ ['le:f.,e:n.heit]
'live' $\rightarrow$ 'family unit'
a. $/ \mathrm{ba}: \mathrm{d} / \mathrm{v} \rightarrow$ ba:t/ + 'r $\rightarrow$ ['ba:t.ər]
'bathe' $\rightarrow$ 'bathe her'
b. $/ \mathrm{xe}: \mathrm{v} / \mathrm{v} \rightarrow$ /xe:f/ + 'm
$\rightarrow$ ['xe:f.əm]
'give' $\rightarrow$ 'give him'

As is clear from the examples in (2a-c) and (3a-b), we can distinguish two types of suffixes, viz., (i) those in which stem-final obstruents may be resyllabified as onsets and (ii) those which trigger devoicing of a stem-final obstruent. We can also distinguish different types of suffixes on the basis of stress behaviour. The problem is that the suffixes that pattern together with respect to resyllabification are not necessarily part of the same class when we consider stress assignment. This will be shown next.

\footnotetext{
${ }^{4}$ The subscripts 'A', 'N', 'V' indicate the morphosyntactic category of the stems and suffixes in question. Syllable boundaries are indicated by a dot. We will discuss syllabification of forms with clitics (as in 5a-b) in more detail in section 5 below.
} 
In Dutch underived words, main stress is assigned to one of the three last syllables in the word. Normally, stress is assigned to the antepenultimate syllable if the penultimate syllable is open and the ultimate one is closed (see 6a). ${ }^{5}$ If the final syllable is "superheavy", i.e., if it ends in a long vowel plus a consonant (-VVC) or a short vowel plus two consonants (-VCC), main stress is usually assigned to the ultimate syllable (see $6 b, c)$.
a. lexikon
['lek.si:.kon]
'lexicon'
b. abrikoos
[a:.bri:.'ko:s]
'apricot'
c. president
[pre:.si:.'dent]
'president'

Otherwise, main stress is usually assigned to the penultimate syllable:
a. pyjama
[pi:.'ja:.ma:]
'pyjamas'
b. Alaska
[ a:.'las.ka:]
'Alaska'
c. elektron
[ e..'lek.tron]
'electron'

With respect to stress assignment, Trommelen \& Zonneveld (1989) distinguish three types of suffixes in Dutch: one type changes the stress pattern of the base, another type requires stress to be assigned to the immediately preceding syllable, and the third type does not cause a stress shift in the base.

Most suffixes belong to the first type. They conform to regular patterns of stress assignment. In the output of (8a), for instance, main stress is assigned to the antepenultimate syllable, because the final syllable is closed and the penultimate syllable is open. In accordance with the rules of regular stress assignment, main stress is assigned to the final syllables in (8b) and (8c), because they are superheavy: ${ }^{6}$

\section{Class I derivation:}
a. /a:.no:.'ni:m/ $\quad+$ us $_{\mathrm{N}} \rightarrow$
[a:.'no:.ni:.mys]
'anonymous writer'
a. /pro:.'dykt/ $+\mathrm{ie} / \mathrm{v} / \mathrm{A} \rightarrow$
[pro:.dyk.'ti:f]
'productive'
b. /pro:.dyk.'ti:v/ + iteit $_{\mathrm{N}} \rightarrow$
[pro:.dYk.ti:.vi:.'teit] 'productivity'

Some adjectival suffixes require that the main stress of the word be located on the syllable preceding the suffix. Examples are -(e)lijk [ələk] and -ig [əx]:

\footnotetext{
${ }^{5}$ In addition to the regular (predictable) pattern, Dutch allows irregular stress assignment in some words (e.g. pelotón, celébes, amérika). For a more detailed analysis of Dutch regular and irregular stress patterns, we refer to Booij (1995) and Trommelen \& Zonneveld (1989).

${ }^{6}$ There are no suffixes which consist of two final light syllables with full vowels, or a light and a heavy syllable, or two heavy syllables and we therefore do not encounter the stress-pattern exemplified in (7a-c) for underived words.
} 
(9) Class II derivation:
a. /'her.tox/ + -elijk
$\rightarrow \quad$ [her.'to:.xə.lək]
'ducal'
b. /do:d/ + -elijk
$\rightarrow \quad$ ['do:.də.lək]
'deadly'
c. /mIz.'da:d/+ -ig
$\rightarrow \quad$ [mIz.'da:.dəx]
'criminal'
d. /leiv/ $+-\mathrm{ig}$
$\rightarrow \quad$ ['lii.vəx]
'corpulent'

Suffixes of type three do not affect the position of the main stress of the word they are attached to. Examples are the nominalising suffixes -aard, -dom, -heid, -ling and -schap and the adjectival suffixes -achtig, -baar, and -loos. Main stress is on the first syllable in the words in (10a-c) below, irrespective of the form of the penultimate or ultimate syllable:

(10) Class III derivation
a. /'her.tox/ + -dom
$\rightarrow \quad[$ 'her.toy.,dom $] \quad$ 'duchy'
b. /'tuei.fəl/ + -achtig
$\rightarrow \quad$ ['tuci.fəl.,ax.təx]
'doubtful'
c /'sxa:.dyv/+ -loos
$\rightarrow \quad$ ['sxa:.dyv.,lo:s] 'without a shadow'

Trommelen \& Zonneveld (1989) assume that inflectional endings and the diminutive suffix belong to the third type, because they do not affect the stress-pattern of the words they are associated to (see 11a) and they may follow derivational suffixes (see 11b,c):
(11)
a. /'her.tox/ + -/jə/ $\rightarrow$ ['her.tox.jə]
'little duke'
b. /ro:d/ + -/axtəx/ + -/ər/ $\rightarrow$ ['ro:t.ax.tə.xər]
'more reddish'
c. /veiv/ +-/lıy/ +-/ən/ $\rightarrow$ ['veif.,lın.ən]
'quintuplets (pl.)'

On the basis of the observations concerning stress assignment, Trommelen \& Zonneveld (1989: 192, 200) propose the following model of the lexicon:

(12)

\begin{tabular}{|lcc|}
\hline & & Underived lexical entries \\
class I affixation & $\leftrightarrow$ & level 1 phonology (syllabification, wordstress) \\
class II affixation & $\leftrightarrow$ & level 2 phonology (syllabification, stress) \\
$\begin{array}{l}\downarrow \\
\text { class III affixation, inflection, } \\
\text { compounding }\end{array}$ & $\leftrightarrow$ & $\begin{array}{c}\downarrow \\
\text { level 3 phonology (compound stress, } \\
\text { adjunction of stress-neutral affixes) }\end{array}$ \\
\hline & & $\begin{array}{c}\downarrow \\
\text { P o s t l e x i c a l L e v e l }\end{array}$
\end{tabular}


This model of the lexicon poses a problem for devoicing phenomena. It presupposes that syllabification only applies at early levels, but not at the level where class III affixation, inflection, and compounding take place. Resyllabification of a stem-final obstruent is indeed attested in words derived by suffixes of the first two types, i.e. suffixes that conform to rules of regular stress assignment (see 8) and suffixes that require main stress before the suffix in question (see 9). Obstruents before schwa-initial suffixes of type three and before inflectional endings are also resyllabified and surface as onsets (see 13). Before suffixes of the third type that have a full vowel, however, stem-final obstruents are not resyllabified and they are voiceless (see 14).

(13) $\underline{\text { Inflection }}$
a. /ro:d/ + -er
$\rightarrow \quad[$ 'ro:.dər $]$
b. /le:v/ + -en
$\rightarrow \quad[$ le:.vən]
'redder'
'(we) live'

(14) Class III derivation:
a. /ro:d/
+ -achtig $\rightarrow$
*[ro:.dax.təx]
b. /ro:d/ $\rightarrow$ /ro:t/ + -achtig $\rightarrow$
['ro:t.ax.tox]
c. /veiv/
+ -ling $\rightarrow$
*[vei.vlin]
d. /veiv/ $\rightarrow$ /veif/ +-ling $\rightarrow$ ['veif.lın]
'reddish'
'quintuplets'

Examples (13a-b) illustrate that resyllabification takes place in the case of inflectional endings, so that the stem-final consonant surfaces as an onset. Examples (14b,d) and (4a-b) illustrate that resyllabification does not take place in the case of other class III affixes and in the case of compound formation. It is thus questionable that inflection belongs to the same level as other class III suffixation and compounding.

Alternatively, it could be argued that inflectional endings belong to a level on which the phonology is organised in such a way that resyllabification is ordered before final devoicing. Other class III suffixes and compounds may be said to belong to a later level on which resyllabification no longer applies, so that final devoicing may apply to stemfinal obstruents. However, in this way, we predict that inflectional endings are attached prior to class III affixation and we incorrectly exclude the possibility that class III affixes may precede inflectional endings, as is the case in the examples in $(11 \mathrm{~b}, \mathrm{c})$ above.

As we have seen, level ordering does not help to explain the different behaviour of suffixes with respect to obstruent devoicing. In our view, the solution to this problem lies in the different prosodic structure of suffixes which trigger resyllabification and suffixes before which we find final devoicing. This will be the topic of section 3 . Before we discuss our solution to this problem, we will first consider a related phenomenon in Dutch which poses an interesting problem for rule ordering. 


\subsection{Voicing assimilation in a rule-based approach}

Final devoicing is often obscured by voicing assimilation and this has been explained in rule-based analyses by a specific ordering of rules for final devoicing and rules for voicing assimilation. Consider in this respect that some class III suffixes which begin in a voiced obstruent trigger voicing assimilation. In most cases, voicing assimilation is regressive and as a result, a stem-final obstruent is voiced before these suffixes (see 10a above and $15 \mathrm{a}-\mathrm{c}$ below): ${ }^{7}$

(15) Regressive voicing assimilation:
a. /e:t/ + -baar
$\rightarrow \quad[$ 'e:d.ba:r $]$
'edible'
b. /vas/ + -baar
$\rightarrow \quad$ ['vaz.ba:r]
'washable'
c. /le:v/ + -baar
$\rightarrow \quad[$ le:v.ba:r]
'liveable'

Progressive voicing assimilation occurs when the right member of a cluster is a fricative, i.e. the fricative assimilates to the obstruent on its left: ${ }^{8}$

$$
\frac{\text { Progressive voicing assimilation: }}{\text { /verk/ + -zaam } \rightarrow} \text { ['verk.sa:m] 'active; effective' }
$$

In clusters with a fricative as the second member, voicing assimilation interacts with final devoicing, i.e. devoicing takes place before progressive voicing assimilation:

(17) Final devoicing and progressive voicing assimilation:
a. /vri:nd/ $\rightarrow$ /vri:nt/ + -schap $\rightarrow$
['vri:nt.sxap]
'friendship'
b. $/ \mathrm{ra}: \mathrm{d} / \mathrm{l} \rightarrow$ ra:t + -zaam $\rightarrow \quad$ 'ra:t.sa:m]
'advisable'

The data in (15) illustrate that devoicing may not take place after regressive voicing assimilation and the data in (17) illustrate that devoicing must take place before progressive assimilation. The order of rules for final devoicing, progressive assimilation, and regressive assimilation is thus as below (Berendsen 1983, Zonneveld 1983):

\footnotetext{
${ }^{7}$ A rule of regressive voicing assimilation is formulated in Berendsen (1983) as follows: [-son] $\rightarrow$ [ $\alpha$ voice] / --- (\#) [-son, $\alpha$ voice $]$

${ }^{8}$ A rule of progressive voicing assimilation is characterised in Berendsen (1983) as follows: [-son, +cont] $\rightarrow$ [-voice] / [-voice] (\#) ---
} 
(18)

\begin{tabular}{|c|c|c|c|}
\hline & ee/t/-/b/aar & lee/v/-/b/aar & |raa/d/-/z/aam \\
\hline $\begin{array}{c}\text { Final devoicing } \\
\Downarrow\end{array}$ & & $\mathrm{f}$ & $\mathrm{t}$ \\
\hline $\begin{array}{c}\text { Progressive ass. } \\
\Downarrow\end{array}$ & & & $\mathrm{t} \mathrm{s}$ \\
\hline Regressive ass. & $\begin{array}{c}\mathrm{d} \text { b } \\
\text { [e:d.ba:r] }\end{array}$ & $\begin{array}{c}\mathrm{v} \mathrm{b} \\
\text { [le:v.ba:r] }\end{array}$ & [ra:t.sa:m] \\
\hline
\end{tabular}

Voicing assimilation is also attested in compounds and across (grammatical) word boundaries. In cases where the second obstruent in a cluster is a stop, regressive voicing assimilation takes place:

(19) Regressive voicing assimilation:
a. $/$ klap/ $+/ \mathrm{d} ø r / \quad \rightarrow$ ['klab.dør]
'swing-door'
b. $/$ stof/ + /duk/ $\rightarrow$ ['stov.duk]
'duster'
c. /hand $/+/$ palm $/ \rightarrow$ ['hant.palm]
'palm'
d. /sto:v/ $\quad+/$ pe:r/ $\rightarrow$ ['sto:f.pe:r]
'stewing-pear'
e. /klap do:r də mo:lən/ $\rightarrow$ [klab do:r də mo:lə]
'a slap by the windmill'

If the second obstruent in a cluster is a fricative, we find progressive voicing assimilation:

(20) Progressive voicing assimilation:
a. /sla:p/
+ /zak $/$
$\rightarrow$ ['sla:p.sak]
'sleeping-bag'
b. /dak/ +/venstər/ $\rightarrow$ ['dak.fen.stər]
'dormer'
c. /as/ $+/ \mathrm{vat} / \rightarrow$ ['as.fat]
'dustbin'
d. /klap van də mo:lən/ $\rightarrow$ [klap fan də mo:lə]
'a slap of the windmill'

Final devoicing has to precede progressive voicing assimilation:

(21) Final devoicing and progressive voicing assimilation:
a. $/$ rond $/ \rightarrow /$ ront/ $+/$ va:rd/ $\rightarrow$ ['ront.fa:rt]
'cruise'
b. $/ \mathrm{xra}: \mathrm{v} / \rightarrow / \mathrm{xra}: \mathrm{f} /+/ \mathrm{zYxt} / \rightarrow[$ 'xra:f.syxt $]$
'digging urge'

The order of rule application in the case of compounds and at the postlexical level is the same as the order of rule application for class III derivation in (18): 
(22)

\begin{tabular}{|c|c|c|c|c|c|}
\hline & klapdeur & slaapzak & rondvaart & klap door & klap van \\
\hline Final devoicing & & & $\mathrm{t}$ & & \\
\hline Progressive ass. & & ps & tf & & $p f$ \\
\hline Regressive ass. & $\begin{array}{c}\text { bd } \\
\text { [klab.dør] }\end{array}$ & [sla:p.sak] & [ront.fa:rt] & $\begin{array}{c}\mathrm{bd} \\
\text { [klab.do:r] }\end{array}$ & [klap.fan] \\
\hline
\end{tabular}

A problem arises when we consider voicing assimilation and the past tense affix - $d e$. This suffix has an initial voiced stop (see 23a) which, according to the rule of regressive voicing assimilation, should trigger voicing of stem-final obstruents. This prediction is not borne out by the facts. Voiceless stem-final obstruents are not voiced before the inflectional ending - $d e$. Instead, after voiceless stem-final obstruents, the morpheme -de is pronounced with voiceless [t] (see $23 \mathrm{~b}, \mathrm{c})^{9}$

(23) Progressive assimilation with inflectional -de:
a. zwaai + -de $\rightarrow$ zwaaide [zva:j.də]
'wave' $\rightarrow$ 'waved'
b. stop +- de $\rightarrow$ stopte
[stop.tə] /*[stob.də]
'stop' $\rightarrow$ 'stopped'
c. maf +- de $\rightarrow$
mafte
[maf.tə]/*[mav.də]
'snooze' $\rightarrow$ 'snoozed'
d. tob + -de $\rightarrow$
tobde
[tob.də]
e. stoov +- de $\rightarrow$ stoofde
[sto:v.də]
'drudge' $\rightarrow$ 'drudged'
'stew' $\rightarrow$ 'stewed'

Another problem concerns devoicing of stem-final obstruents before clitics. In (24a) we find an instance of a clitic with an initial voiced plosive. According to the rule-ordering that was established in (22) for the post-lexical level, one might expect that a preceding obstruent is voiced due to voicing assimilation (see the last two columns in 25). This is not the case for all speakers, however: ${ }^{10}$

\footnotetext{
${ }^{9}$ Zonneveld (1983) proposes that the past tense suffix actually begins in a voiced fricative / $/$ / (which is not a phoneme in Dutch). After the rules of final devoicing, progressive assimilation, and regressive assimilation have applied, the resulting voiced or voiceless fricative is transformed into a plosive. Booij (1995:61-64) proposes that the underlying initial stop of the past tense suffix is unspecified for [voice]. He furthermore assumes a phonological rule that spreads the Laryngeal node from a preceding vowel or consonant to this stop. In section 4 below, we present an alternative analysis that neither assumes an underlying voiced fricative, nor underspecification.

${ }^{10}$ The data below are taken from the literature (Berendsen 1983, Booij 1995), but there is a great degree of variety among speakers of Dutch with respect to these forms. We assume with Berendsen (1983:29) coherency for the data in the sense that they may occur in one speaker/hearer.
} 
(24) No regressive assimilation with clitics:
a. kan + die $\rightarrow$ kan-die [kandi:]
'can he'
b. vond + die $\rightarrow$ vontie [vonti] / *[vonddi]
'found he'
c. of + die $\rightarrow$ of-tie
[ofti] / *[ovdi]
'whether he'

Below, we illustrate that the rule-order established in (18) and (22) makes the wrong predictions for the past-tense suffix -de and the clitic die:

\begin{tabular}{|c|c|c|c|c|}
\hline & stop-de & tob-de & vond-die & of-die \\
\hline $\begin{array}{c}\text { Final devoicing } \\
\Downarrow\end{array}$ & & $\mathrm{p}$ & $\mathrm{t}$ & \\
\hline $\begin{array}{c}\text { Progressive ass. } \\
\Downarrow\end{array}$ & & & & \\
\hline Regressive ass. & $* \mathrm{~b} d$ & $* \mathrm{pt}$ & $* \mathrm{~d} \mathrm{~d}$ & $* \mathrm{vd}$ \\
\hline
\end{tabular}

In summary, we found that the level ordering that can be established on the basis of stress assignment does not help to explain the different behaviour of inflectional suffixes and other class III suffixes with respect to final devoicing (see section 2.1). Furthermore, we showed that the order of rules that is needed to explain examples with some class III suffixes, compounds, and the behaviour of consonant clusters across word boundaries does not explain forms which are built by the suffix -de and forms which involve clitics. We will address the first issue in section 3. In section 4 , we deal with voicing effects when the past tense morpheme -de is involved and section 5 discusses final devoicing and clitics.

\section{The prosodic structure of affixes}

To explain the different behaviour of suffixes with respect to final devoicing, voicing assimilation, and stress in Dutch and to explain phonological phenomena which may or may not apply in different morphosyntactic environments in other languages, Booij (1995:111 ff.) and Selkirk (1995), respectively, make the following suggestion. In their view, there are different categories of suffixes. The first category consists of suffixes that do not form a Prosodic Word of their own. We will refer to these suffixes as 'internal suffixes', because they become part of a larger Prosodic Word. The second category consists of suffixes that form a Prosodic Word of their own and that have an internal stress pattern. From now on, these suffixes will be referred to as 'external suffixes'. The prosodic structure of the latter suffixes ensures that stem-final obstruents 
are not resyllabified as onsets of the suffix-initial syllable (26b). ${ }^{11}$ Selkirk (1995) proposes that the morphosyntactic word structure for all suffixes is the same (26a), but the prosodic word structure may be different $(26 \mathrm{~b}) .{ }^{12}$ We illustrate this idea by representing the morphosyntactic word structure and the prosodic word structure for examples (13a) and (14b), respectively:

a. Morphosyntactic word structure

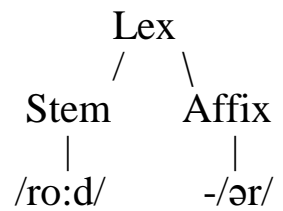

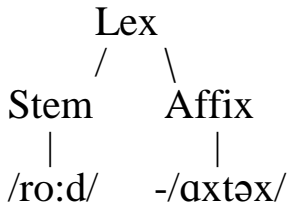

b. Prosodic word structure "internal affix" "external affix" ( ro:.dər ) $\omega$ $(\text { ro:d })_{\omega}(\operatorname{axt\partial x})_{\omega}$

We will assume in the remainder of this paper that the categories 'internal affix' and 'external affix' are specified as such in the lexicon. The prosodic structure of the respective affixes is not specified underlyingly, but assigned by the grammar. Inkelas (1994b) assumes for Turkish that in some instances, prosodic structure is not assigned by constraint-ranking, because this would supposedly necessitate morpheme-specific constraints. She therefore prespecifies prosodic structure in the lexicon for some morphemes. For Dutch, however, no morpheme-specific constraints need to be stipulated. We will propose constraints which refer to morphological categories and not to particular morphemes.

\subsection{Final devoicing}

In (27b) it is shown that an underlyingly voiced obstruent $(/ \mathrm{v} /)$ is realised as such when it surfaces in onset position. In (27c), the fricative is in front of a vowel-initial suffix, but it does not resyllabify as an onset. Due to the fact that it finds itself in a syllablefinal position, it is devoiced:

\footnotetext{
${ }^{11}$ In the remainder of this paper, we will use round brackets as boundary markers for the prosodic categories 'Prosodic Word' (PWd) and 'Phonological Phrase' (PPh). Also, the symbol ' $\omega$ ' denotes 'Prosodic Word'.

${ }^{12}$ Following Selkirk (1995:440), 'Lex' (lexical word) designates a morphosyntactic word belonging to a lexical category, i.e. $\mathrm{N}^{0}, \mathrm{~V}^{0}$, or $\mathrm{A}^{0}$.
} 

a. die/v/ $\rightarrow$ ('di:f)
'thief'
b. die/v/ + -en $\rightarrow$ ('di:.vən)
'thieves'
c. die/v/ + -achtig $\rightarrow$
('di:f)(,ax.təx)
'thievish'

The challenge is to account for the fact that a stem-final obstruent may resyllabify before some vowel-initial suffixes, but not before other ones. In section 2.1, we argued that a derivational account for final devoicing has serious shortcomings. We will now suggest a constraint-based nonderivational account.

In Optimality Theory (Prince \& Smolensky 1993), output forms have to meet certain conditions or constraints. The output form in (27b) illustrates that, when possible, syllables should have onsets. This is generally contributed to the constraint ONSET:

ONSET (Ons) A syllable has an onset.

In (27c), the stem-final obstruent does not become an onset of the next syllable. We will argue now that this behaviour is due to the fact that suffixes like the one in (27b) are internal suffixes, whereas those like the one in $(27 \mathrm{c})$ form a Prosodic Word of their own.

We attribute the behaviour with respect to syllabification of stems and internal suffixes to the requirement that a Prosodic Word must correspond to a lexical word (here: stem + suffix). Selkirk (1995:445) formulates such a type of constraint in terms of Generalized Alignment (McCarthy \& Prince 1993):

(29) Align (PWd, R, Lex, R):

Align the right edge of every Prosodic Word with the right edge of some lexical word $(\mathrm{N}, \mathrm{V}$, or $\mathrm{A})$.

The prosodic structure in (30) for the form in (9c) illustrates that the Prosodic Word is right aligned with a lexical word (here an adjective) and that internal suffixes are inside a Prosodic Word:

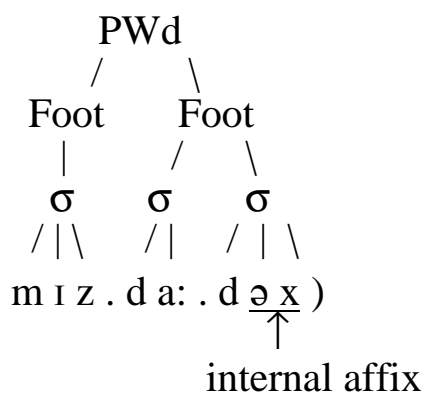

We will argue below that the Prosodic Word is the relevant domain for final devoicing in Dutch. In this paper, we defend the view that final devoicing may be formulated as a 
locally restricted markedness constraint against voicing in obstruents. In particular, we will argue in favour of a context-free constraint against voicing in obstruents (31c) and in favour of specific constraints against voicing in obstruents at the end of prosodic domains, e.g. at the end of a Prosodic Word (31a) or a syllable (31b).

$$
\begin{array}{ll}
\text { a. PWD-Final Devoicing: } & *[+ \text { voice }]) \omega \\
& \text { i.e., word final obstruents are voiceless. }
\end{array}
$$

b. Syllable-Final Devoicing: * [+voice] ) $\sigma$ i.e., syllable final obstruents are voiceless.

\section{c. Devoicing:}

* [+voice]

i.e., obstruents are voiceless.

At this point, it is not crucial whether Dutch devoicing is analysed as syllable final, foot final, or Prosodic Word final. However, in section 4 we will show that the fact that syllable final devoicing is obviously ignored within the Prosodic Word in (32a) but not across the Prosodic Word boundary in (32b) can be attributed to the different ranking of (31a) and (31b) with respect to Identity constraints.

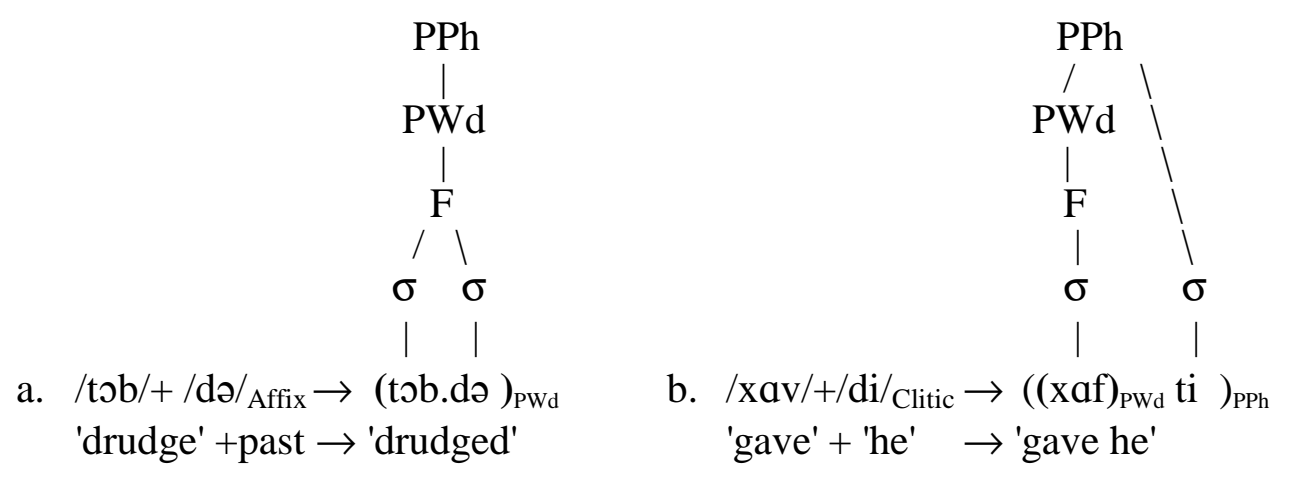

In (32a), PWD-FInAL DEVOICING is vacuous and the identity of the underlying voicing specification of both the stem-final obstruent and the affix-initial obstruent remains unaltered. This example shows that (31b) may be violated in favour of keeping the underlying voicing specification intact. In (32b), the constraint formulated in (31a) plays an important role, since the underlying voicing specifications of both obstruents are lost in order to comply with this constraint. In anticipation of the discussion in section 4.1, we will use (31a) here to explain final devoicing before some vowel-initial affixes and before vowel-initial clitics. 
The following tableau illustrates that the three constraints mentioned in (28), (29), and (31a) give the correct output for the verbal stem /xe:v/ and the nominalizing affix /or/: ${ }^{13}$

\begin{tabular}{|c|c|c|c|c|}
\hline (33) & /xe:v/ + -/ər/ & 'somec & e who gives' & \\
\hline & $\begin{array}{l}\text { Input: } \\
\text { xe: } v_{\text {Stem }}+\partial r_{\text {Affix int }}\end{array}$ & $\begin{array}{l}\text { Align R } \\
\text { PWd }\end{array}$ & $\begin{array}{l}\text { PWd-Final } \\
\text { Devoicing }\end{array}$ & Onset \\
\hline a. & {$[(\mathrm{xe}: \mathrm{v}) . . \mathrm{r}]$} & $* !$ & $*$ & $*$ \\
\hline b. & [(xe:f) .or ] & $* !$ & & $*$ \\
\hline c. & [(xe:).vər ] & $* !$ & & \\
\hline d. & [(xe: .vər)] & & & \\
\hline e. & [(xe:v. or)] & & & $* !$ \\
\hline
\end{tabular}

( ) = PWd boundaries; [] = Lex boundaries

Candidate (33a) violates the constraint formulated in (31a), because the Prosodic Word final obstruent $[\mathrm{v}]$ is not voiceless. In candidates $(33 \mathrm{a}, \mathrm{b}, \mathrm{c})$, the right edge of the Prosodic Word is not the right edge of a lexical word and this violates (29). Candidates (33a,b,e) violate ONSET. Candidate (33d) does not violate any of the constraints mentioned above and it is thus the winner or the 'optimal' candidate.

Below we show a tableau for a lexical word which consists of a stem followed by two internal affixes. The constraint requiring that a lexical word must correspond to one Prosodic Word (see 29) is violated in (34a,b) because the only Prosodic Word is not at the right edge of a lexical word. The winning candidate (34d) has an onset and, hence, one violation less than $(34 \mathrm{c})$ :

(34) /pro:dykt/ + -/i:v/ + -/iteit/ <productiviteit> 'productivity'

\begin{tabular}{|c|c|c|c|c|}
\hline & $\begin{array}{l}\text { Input: } \quad \text { pro:dykt }_{\text {Stem }}+ \\
{\text { i }: \mathrm{v}_{\text {Affix }} \text { int }}+{\text { it } \varepsilon i t_{\text {Affix int }}}+ \\
\end{array}$ & $\begin{array}{l}\text { Align R } \\
\text { PWd }\end{array}$ & $\begin{array}{l}\text { PWd-Final } \\
\text { Devoicing }\end{array}$ & Onset \\
\hline a. & [ (pro:dykt).i:.vitcit ] & $* !$ & & $*$ \\
\hline $\mathrm{b}$. & [ (pro:dyk ti:v).i.teit ] & $* !$ & $*$ & $*$ \\
\hline c. & [ (pro:dyk.ti:f.i.teit) ] & & & $* !$ \\
\hline d. & [ (pro:dyk.ti:.vi.tcit)] & & & \\
\hline
\end{tabular}

We still have to account for the fact that stem-final obstruents are voiceless before the so-called 'external suffixes' and in compounds. Stem-final obstruents cannot be onsets of external suffixes due to the fact that external suffixes form a Prosodic Word of their own. The constraint that ensures that external suffixes form an independent Prosodic

\footnotetext{
${ }^{13}$ For most tableaux in this section, a more detailed tableau with more possible candidates is given in the appendix.
} 
Word domain is a morphology/prosody Alignment constraint that says that the left edge of an external suffix coincides with the left edge of a Prosodic Word:

\section{Align (Affix ext $_{1}, \mathrm{~L}$, PWd, L)}

Align the left edge of every external affix with the left edge of some Prosodic Word.

In tableau (36), the constraint formulated above is violated in candidates a-d. The constraint must be ranked higher than ALIGN RIGHT PWD, because it incurs a fatal violation in candidate (36d). Candidate (36e) violates ALIGN RIGHT PWD and PWDFinAL DeVoicing and candidate (36f) wins, even though it violates ALIGN RigHT PWD and low-ranked ONSET.

\begin{tabular}{|c|c|c|c|c|c|}
\hline$(36)$ & /di:v/ + -/axtəx/ & achtig> & 'thievi & & \\
\hline & $\begin{array}{l}\text { Input: } \\
\operatorname{div}_{\text {Stem }}+\operatorname{axtəx}_{\text {Affix ext }}\end{array}$ & $\begin{array}{l}\text { Align L } \\
\text { Affix }_{\text {ext }}\end{array}$ & $\begin{array}{c}\text { Align R } \\
\text { PWd }\end{array}$ & $\begin{array}{l}\text { PWd-Final } \\
\text { Devoicing }\end{array}$ & Onset \\
\hline a. & [(di:v). ax.təx ] & $* !$ & $*$ & $*$ & $*$ \\
\hline b. & [(di:f). ax.təx ] & $* !$ & $*$ & & * \\
\hline c. & [(di:).(vax.tox $)]$ & $* !$ & $*$ & & \\
\hline d. & [(di:.vax.təx $)]$ & $* !$ & & & \\
\hline e. & [(di:v).(ax.təx)] & & $*$ & *! & $*$ \\
\hline f. $\sigma^{\circ}$ & {$[(d i: f) .(a x \cdot t \partial x)]$} & & $*$ & & $*$ \\
\hline
\end{tabular}

Now consider the situation where an internal affix and an external affix are involved. Below, we illustrate that the constraints proposed in this section account for final devoicing before external affixes and for the fact that final obstruents of external affixes may be onsets of internal affixes. In candidate (37d), a violation of ALIGN LEFT AFFIX is fatal, whereas the violation of ALIGN RIGHT PWD is not fatal in candidate (37f). This means that the former constraint is ranked higher than the latter:

(37) /ro:d/ + -/axtəx/ + -/ər/ <roodachtiger> 'more reddish'

\begin{tabular}{|c|c|c|c|c|c|}
\hline & 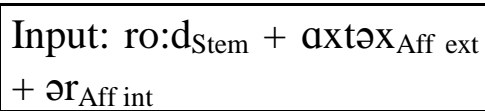 & $\begin{array}{l}\text { Align L } \\
\text { Affix }_{\text {ext }}\end{array}$ & $\begin{array}{l}\text { Align R } \\
\text { PWd }\end{array}$ & $\begin{array}{l}\text { PWd-Final } \\
\text { Devoicing }\end{array}$ & Onset \\
\hline a. & {$[($ ro:d). ax.təx .ər] } & $* !$ & $*$ & $*$ & $* *$ \\
\hline b. & [(ro:t). ax.təx .ər] & $* !$ & $*$ & & $* *$ \\
\hline c. & [(ro:t). (ax.təx).ər] & & $* * !$ & & $* *$ \\
\hline d. & [(ro:. dax. tə. xər)] & $* !$ & & & \\
\hline e. & [(ro:t). (ax.tə).xər] & & $* * !$ & & $*$ \\
\hline f. & [(ro:t). (ax.tə.xər)] & & $*$ & & $*$ \\
\hline
\end{tabular}


To ensure that in compounds both members form a Prosodic Word of their own, we suggest the following morphology/prosody Alignment constraint:

\section{Align (Stem, L, PWd, L)}

Align the left edge of every stem with the left edge of some Prosodic Word.

This constraint has to be ranked higher than the constraint that says that the right edge of a Prosodic Word coincides with the right edge of a Lexical word (see 29):

\begin{tabular}{|c|c|c|c|c|c|}
\hline (39) & /xoud/ + /a:dər/ & er> & gold-vein & & \\
\hline & $\begin{array}{l}\text { Input: } \\
\text { xoud }_{\text {Stem }}+\mathrm{a}: \text { dər }_{\text {Stem }}\end{array}$ & $\begin{array}{l}\text { Align L } \\
\text { Stem }\end{array}$ & $\begin{array}{c}\text { Align R } \\
\text { PWd }\end{array}$ & $\begin{array}{l}\text { PWd-Final } \\
\text { Devoicing }\end{array}$ & Onset \\
\hline a. & [(xoud).a:.dər ] & $* !$ & $*$ & $*$ & * \\
\hline b. & [(xəut). a:.dər] & $* !$ & $*$ & & * \\
\hline c. & {$[(\mathrm{x} \supset u) .(\mathrm{da}: . \mathrm{d} r \mathrm{r})]$} & $* !$ & $*$ & & \\
\hline d. & [(xəu.da:.dər)] & $* !$ & & & \\
\hline e. & [(xoud).(a:.dər)] & & $*$ & $* !$ & $*$ \\
\hline f. $\rightarrow$ & [(xout) .(a:.dər)] & & $*$ & & $*$ \\
\hline
\end{tabular}

This is not the end of the story, however. There is another element with the same form as the suffix /or/. This element is a clitic and it behaves differently. In particular, stemfinal obstruents may be voiced before the affix -/or/ (see 33d), whereas stem-final obstruents are always voiceless before vowel-initial clitics. We here suggest that this may be attributed to the different prosodic requirements of stems, suffixes, and clitics. Schwa-initial suffixes have to be incorporated into a prosodic structure, whereas the weak forms of personal pronouns are clitics. Such clitics are degenerate syllables which are not part of the Prosodic Word. Rather, they are adjuncts that do not belong to the same Prosodic Word as their hosts: ${ }^{14}$

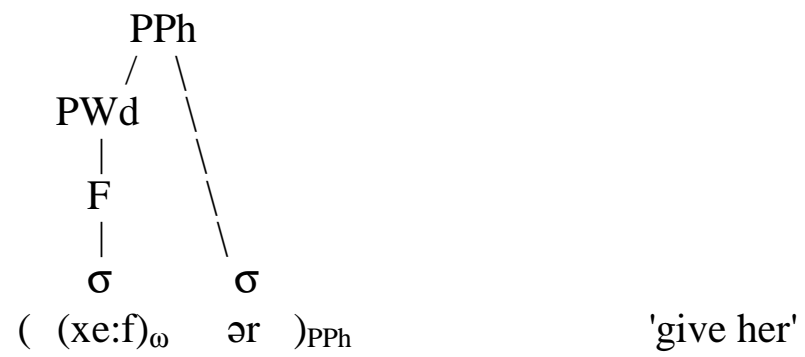

\footnotetext{
${ }^{14}$ Selkirk (1995) refers to elements which do not belong to a Prosodic Word as 'free' elements. We will discuss the prosodic structure of clitics in more detail in section 5.
} 
If we assume that the host of a pronominal clitic is a lexical word, the constraint ranking established thus far correctly predicts final devoicing before clitics. The tableau in (41) differs from the one in (33) in that there is no internal affix involved and a Prosodic Word boundary is not required to the right of the clitic -or. Tableau (41) also illustrates that PWD-FInAL DEVOICING and ALIGN Right PWD may not be violated in the optimal form, whereas ONSET may be violated. The latter constraint should therefore be ranked lower than PWD-FinAl DEVOICING and ALIGN RighT PWD.

\begin{tabular}{|c|c|c|c|c|}
\hline$(41)$ & /xe:v/ + /ər/ & 'give h & & \\
\hline & $\begin{array}{l}\text { Input: } \\
\text { xe: } v_{\text {Stem }}+\partial r_{\text {Clitic }}\end{array}$ & $\begin{array}{c}\text { Align R } \\
\text { PWd }\end{array}$ & $\begin{array}{l}\text { PWd-Final } \\
\text { Devoicing }\end{array}$ & Onset \\
\hline a. & {$[(\mathrm{xe}: \mathrm{v})]$.ər } & & $* !$ & $*$ \\
\hline b. & [(xe:f)] .ər & & & $*$ \\
\hline c. & {$[(\mathrm{xe}:) . \mathrm{v}]$ or } & $* !$ & & \\
\hline d. & {$[(\mathrm{xe}: \mathrm{v}]$ or $)$} & $* !$ & & \\
\hline e. & [(xe:f] .ər) & $* !$ & & $*$ \\
\hline
\end{tabular}

In this section, we have provided a constraint-based account of final devoicing in Dutch. The distinction between internal suffixes and external suffixes plays a crucial role in our analysis. We have proposed one Alignment constraint for Prosodic Words, one for external suffixes, and one for stems, respectively. They are ranked as in (42a):

\section{(42) Constraint Ranking}

a. Align L Affix ${ }_{\text {ext }}$, Align L Stem $\gg$ Align R PWd $>$ Onset

b. PWd-Final Devoicing $>>$ Onset

Inkelas (1994b) develops an account of exceptional stress patterns in Turkish. She argues that these patterns are best analysed in the lexicon with underlying metrical structure. For Dutch, a prespecification approach implies that stems and external suffixes are specified with a trochaic foot in the input. Furthermore, a constraint is needed which says that a segment at the left edge of a foot in the input is also at the left edge of a foot in the output (ANCHOR LEFT). As an example of how such an account would work, we present the following tableau: 


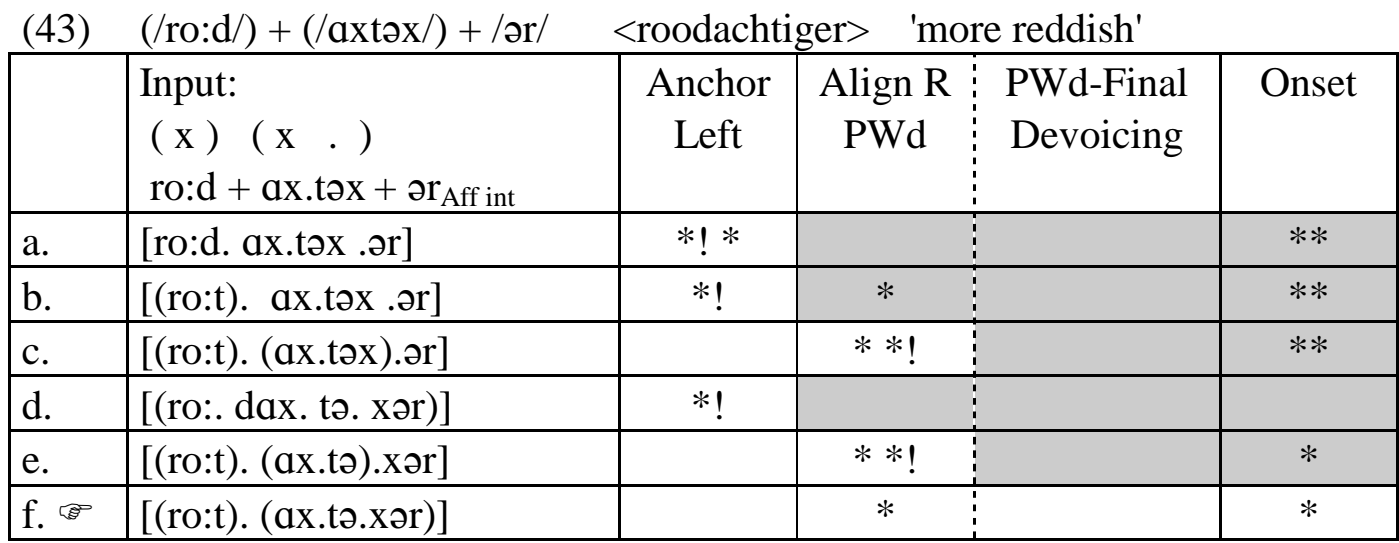

We consider it a drawback of this analysis that all stems and many affixes are specified for foot structure underlyingly, even more so, because a high ranked constraint which says that feet in Dutch are moraic trochees would have to be assumed any way to account for secondary stress (see, e.g., Kager 1996). It does not seem to be very economic to have both underlying feet and feet which emerge as the result of the grammar by constraint ranking. We therefore prefer an analysis in which the grammar is responsible for prosodic structure.

In the next section, we will consider a constraint-based analysis for voicing assimilation.

\section{An OT-account of final devoicing and voicing assimilation}

A recent explanation for part of the Dutch data is found in Lombardi $(1995,1996)$. She defends the position that there is no feature specification [-voice]. In her view, voicing in obstruents is expressed by the presence of a Laryngeal node. To account for devoicing, Lombardi (1996) proposes a constraint which prohibits segments with features for voicing (*Lar). This markedness constraint interacts with faithfulness constraints which say that underlying featural specifications should remain the same. One group of familiar faithfulness constraints are the so-called 'Identity constraints' introduced by McCarthy \& Prince (1995):

(44) IDENT(F) (McCarthy \& Prince 1995:264)

Let $\alpha$ be a segment in $S_{1}$ and $\beta$ be any correspondent of $\alpha$ in $S_{2}$.

If $\alpha$ is $[\gamma \mathrm{F}]$ then $\beta$ is $[\gamma \mathrm{F}]$.

(Correspondent segments are identical in feature F.)

Lombardi $(1995,1996)$ points out that it is usually more important to be faithful to onset laryngeal specifications than to coda - or elsewhere - specifications. In different papers, 
she suggests different strategies to express this generalisation. Lombardi (1995) proposes the Alignment constraint in (45) which captures this generalisation and Lombardi (1996) proposes to limit the scope of Identity constraints by so-called 'positional' requirements to ensure that obstruents in onset positions do not devoice. The identity constraint in (46) requires that the underlying voice value of an obstruent surfaces if it is realised in onset position:

\section{(45) Align Left (Laryngeal, Syllable):}

Every Laryngeal node stands at the left edge of a syllable.

(46) IDENTONSET(Laryngeal) (IDOnsLar):

Onsets should be faithful to underlying laryngeal specification.

The two constraints have the same effect and in the remainder of this paper we will adopt the option of a positional requirement on Identity Constraints to express the fact that voicing features in the onset are preserved, but nothing crucial hinges on this choice.

In Dutch, a laryngeal specification (i.e., the emergence of voiced obstruents) is only allowed in onsets. This is guaranteed in Lombardi's (1996) analysis by the ranking IDONSLAR >> *Lar > IDENTLARYNGEAL:

(47) <daad> 'deed'
\begin{tabular}{|l|l|c|c|c|}
\hline & Input: /da:d/ & IDOnsLar & $*$ Lar & $\begin{array}{c}\text { IDent } \\
\text { Laryngeal }\end{array}$ \\
\hline a. & {$[$ da:d] } & & $* * !$ & \\
\hline b. & {$[$ ta:t $]$} & $* !$ & & $* *$ \\
\hline c. $\%$ & {$[$ da:t $]$} & & $*$ & $*$ \\
\hline
\end{tabular}

Lombardi suggests that assimilation is due to a constraint AGREE that requires adjacent obstruents to have the same value for voicing:

(48) AGREE: Obstruent clusters should agree in voicing.

The AGREE constraint as formulated above is neither a markedness constraint nor a correspondence constraint. As it stands, it does not belong to any constraint family proposed in the literature. We doubt the necessity of positing a new constraint scheme. Instead, we propose to substitute AGREE by an Identity constraint. Consider in this respect, that assimilation is an identity relation that requires that neighbouring segments look identical in some respect (e.g. with respect to voicing). Following Krämer (1998), who proposes that vowel harmony is best expressed as an identity relation among 
surface elements, we formulate the constraint which expresses voicing assimilation as follows:

(49) SuRface-IDENTITy[voice] (S-IDENT):

Let $\alpha$ be an obstruent in a string and $\beta$ be any adjacent obstruent in that string. If $\alpha$ is [ $\gamma$ voice] then $\beta$ is [ $\gamma$ voice].

(Adjacent obstruents are identical in voicing.)

In a cluster of two obstruents where one of the obstruents appears in onset position, this obstruent will be faithful to its voicing specification at the cost of the underlying voicing specification of its leftward neighbour. This is ensured in Lombardi's analysis, because she ranks IDONSLAR above the markedness constraint on voiced obstruents (*Lar):

\begin{tabular}{|c|c|c|c|c|c|}
\hline$(50)$ & /kas/ + /buk $/$ & oek> & 'cash-book & & \\
\hline & Input: /kas/ + /buk/ & S-Ident & IDOnsLar & *Lar & IDLar \\
\hline a. $\oplus$ & [kaz.buk] & & & $* *$ & $*$ \\
\hline b. & [kas.puk] & & $* !$ & & $*$ \\
\hline c. & [kas.buk] & $* !$ & & $*$ & \\
\hline
\end{tabular}

However, examples with fricatives as second members of consonant sequences $(16,17$, 20, and 21) show that voicing is not always preserved in onsets. In Lombardi's analysis, constraint (51) is assumed to account for the fact that the positional constraint on onsets may be obscured in the case of fricatives:

$$
\begin{array}{r}
\text { Postobstruent Fricative Voicing constraint (FricVoice): } * \text { [-son] [-son] } \\
{[+ \text { cont }]} \\
{[+ \text { voice }]}
\end{array}
$$

Lombardi acknowledges that this constraint is not very elegant and in section 4.2, we will propose to an analysis which does not use this constraint.

In the following tableau, Lombardi's analysis is exemplified for a case where it works properly. Ranking FRICVOICE and S-IDENT above IDONSLAR will give the correct output for a case where the input consists of a voiced plosive followed by a voiced fricative: 


(52)
/ra:d/ + /za:m/ <raadzaam> 'advisable'
\begin{tabular}{|l|l|c|c|c|c|c|}
\hline & Input: /ra:d/ + /za:m/ & FricVoice & S-Ident & IDOnsLar & $*$ Lar & IDLar \\
\hline a. & [ra:d.za:m] & $* !$ & & & $* *$ & \\
\hline b. & [ra:t.za:m] & $* !$ & $*$ & & $*$ & $*$ \\
\hline c. & [ra:d.sa:m] & & $* !$ & $*$ & $*$ & $*$ \\
\hline d. $*$ & {$[$ ra:t.sa:m] } & & & $*$ & & $* *$ \\
\hline
\end{tabular}

Lombardi $(1995,1996)$ is not concerned with inflection and clitics and her proposal does not exhaustively explain the Dutch facts. This is demonstrated below. The little deadhead ( $*$ ) marks the winning form in Lombardi's grammar and the sad smiley (:) marks the actual output of the Dutch grammar.

\begin{tabular}{|c|c|c|c|c|c|c|}
\hline (53) & <klapte> clapt & & & & & \\
\hline & Input: /klap/ +/ də/ & FricVoice & S-Ident & IDOnsLar & *Lar & IDLar \\
\hline a. $\stackrel{2}{x}$ & [klabdə] & & & & $* *$ & $*$ \\
\hline b. : : & [klaptə] & & & $* !$ & & $*$ \\
\hline c. & [klabtə] & & $* !$ & $*$ & $*$ & $* *$ \\
\hline d. & [klapdə] & & $* !$ & & $*$ & \\
\hline
\end{tabular}

(54) <mafte> 'snoozed'

\begin{tabular}{|c|c|c|c|c|c|c|}
\hline & Input: /maf/ + /də/ & Fric Voice & S-Ident & IDOnsLar & *Lar & IDLar \\
\hline a. $\stackrel{2}{x}$ & [mavdə] & & & & $* *$ & $*$ \\
\hline b. : : & [maftə] & & & $* !$ & & $*$ \\
\hline c. & [mavtə] & & $* !$ & $*$ & $*$ & $* *$ \\
\hline d. & [mafdə] & & $* !$ & & $*$ & \\
\hline
\end{tabular}

(55) <gaf-tie> 'gave he'

\begin{tabular}{|l|l||l|c|c|c|c|}
\hline & Input: /xav/ +/di/ & Fric Voice & S-Ident & IDOnsLar & $*$ Lar & IDLar \\
\hline \hline a. $\&$ & {$[$ xavdi $]$} & & & & $* *$ & \\
\hline b. $:$ & {$[$ xafti $]$} & & & $* !$ & & $* *$ \\
\hline c. & {$[$ xavti $]$} & & $* !$ & $*$ & $*$ & $*$ \\
\hline d. & {$[$ xafdi $]$} & & $* !$ & & $*$ & $*$ \\
\hline
\end{tabular}

These data will be accounted for in the following sections. 


\subsection{Prosodic structure and voicing assimilation}

On the basis of the observation that stem-final obstruents resyllabify before some suffixes but not before others and neither before clitics, we concluded in section 3 that Dutch distinguishes between internal and external affixes and 'free' clitics. If we are right in this respect, the solution to the problem concerning voicing assimilation in the case of inflectional suffixes may become more transparent. The difference between (50) and (52) on the one hand, and (53), (54) and (55) on the other hand lies in the fact that in the former cases, we are dealing with forms that consist of two Prosodic Words, whereas there is only one Prosodic Word in (53-55):

$$
\begin{aligned}
& \text { Stem }+ \text { Stem } \quad \text { Stem }+ \text { Affix }_{\text {ext. }} \quad \text { Stem }+ \text { Affix }_{\text {int. }} \quad \text { Stem+Clitic } \\
& \text { a. Input /kas/ + /buk/ /ra:d/+/za:m/ /maf/+/də/ /xav/ +/di/ } \\
& \text { b. Output }[(\mathrm{kaz}) \quad(\mathrm{buk})] \quad[(\mathrm{ra}: \mathrm{t})(\mathrm{sa}: \mathrm{m})] \quad\left[\begin{array}{lll}
(\mathrm{maf} & \mathrm{t})
\end{array}\right] \quad[(\mathrm{xaf})] \text { ti }
\end{aligned}
$$

The output forms in (56b) show that a plosive in onset position of a Prosodic Word is faithful to its underlying voicing specification, whereas a plosive in the onset of a syllable which is not initial in a Prosodic Word may not be faithful when other conditions are at play (e.g. devoicing and/or voicing assimilation). We propose to add another specific positional requirement to Lombardi's Identity constraint in (46) in such a way, that it does not refer to all syllable onsets, but only to those in Prosodic Word initial position: ${ }^{15}$

(57) IDENT PWD-ONSET (voice):

Onsets of Prosodic Words should be faithful to underlying laryngeal specification.

Furthermore, we note that the fricative in onset position of a Prosodic Word is not faithful to its underlying voicing specification in raadzaam [ra:tsa:m] 'advisable'. Lombardi (1996) proposes the 'postobstruent voiced fricative constraint' in (51) to exclude the outcome *[ra:dza:m] (see 52). In the current theoretical framework, there are no constraints on the way markedness constraints can be formulated and the supposed existence of a constraint such as the one in (51) opens the door to, for instance, constraints which require all segments following an obstruent to be a labial nasal or to be aspirated, etc. Obviously, this is not desirable and we choose not to adopt

\footnotetext{
${ }^{15}$ This constraint could also be formulated as an Alignment constraint: ALIGN LEFT ([+voice], PWd). The constraint says that every feature [+voice] stands at the left edge of a Prosodic Word. We assume that universally, the more specific version of a constraint is ranked higher than the more general version, i.e., if we assume Identity, IDENT PWD-ONSET (voice) is ranked higher than the more general constraint IDENT ONSET (voice) which, in turn, is ranked higher than IDENT (voice).
} 
this constraint in our analysis. Based on the observation that voiced fricatives are more marked than voiced stops, we propose here that it is more important to preserve an underlying voice-specification for stops than for fricatives: ${ }^{16,17}$

\section{(58) IDENT STOP (voice):}

Let $\alpha$ be a stop in $S_{1}$ and $\beta$ be any correspondent of $\alpha$ in $S_{2}$.

If $\alpha$ is [ $\gamma$ voice] then $\beta$ is [ $\gamma$ voice].

(Stops should be faithful to underlying laryngeal specification.)

Combining the two requirements regarding faithfulness to voicing specifications in onset position of Prosodic Words and faithfulness to voicing specifications for stops, we arrive at the following constraint which will be crucial to our analysis:

IDENT PWD-ONSET STOP (voice):

Let $\alpha$ be a stop in $S_{1}$ and $\beta$ be any correspondent of $\alpha$ in onset position of a Prosodic Word in $S_{2}$. If $\alpha$ is [ $\gamma$ voice] then $\beta$ is [ $\gamma$ voice].

(Stops in onsets of Prosodic Words should be faithful to underlying laryngeal specification.)

With this constraint, we have eliminated the need of an ad hoc constraint like FricVoice in (51). However, it predicts that suffixes with an initial voiced fricative (e.g. -zaam) would always be realised with a voiceless obstruent (due to *Lar or *VOICE). This is not the case (cf. eenzaam [e:nza:m]/ *[e:nsa:m] 'lonely'). For this reason, we propose to add constraints which limit the scope of the constraint $*$ VOICE to final positions in syllables and Prosodic Words (see 31b and 31a, respectively, the latter is repeated here for convenience as 60$):^{18}$

$$
\text { PWD-FinAl Devoicing: }
$$

$$
\begin{aligned}
& *[+ \text { voice }]) \omega \\
& \text { i.e., word final obstruents are voiceless. }
\end{aligned}
$$

\footnotetext{
${ }^{16}$ Instead of the Laryngeal node, we make use of the binary valued feature [+/-voice], because we find Inkelas' (1994a) arguments in favour of this feature convincing. Also, Butska (1998) and Krämer (1999) show on the basis of Ukrainian voicing phenomena and Breton voicing assimilation, respectively, that a specification for voicing cannot be privative. However, for the purpose of this paper, nothing crucial hinges on this.

17 IDENTITY PWD-ONSET STOP (voice) can be interpreted as the local conjunction (see Smolensky 1993, 1995) of the two more general identity constraints IDENTITY PWD-ONSET (voice) and IDENTITY STOP (voice) which are ranked lower than the more specific constraint.

${ }^{18}$ In examples (32a) and (32b) above, we have indicated that PROSODIC WORD-FINAL DEvOICING is relevant. Below, we will provide further evidence for the positional restrictions of constraints against voicing in obstruents.
} 
The constraint in (60) cannot be ranked lower than the context-free constraint IDENT (voice), otherwise we would never see an effect of PROSODIC WORD-FINAL DEVOICING. This constraint helps to select the winning candidate in (61). The constraint in (59) applies vacuously in (61) because there is no onset stop at play, but it is crucial in selecting the winning candidate in cases where the second obstruent in a cluster is a plosive (see 62, 64 below).

(61) <raadzaam> 'advisable'

\begin{tabular}{|l|l|c:l|c|}
\hline & $\begin{array}{l}\text { Input: } \\
\text { /ra:d/ +/za:m/ }\end{array}$ & $\begin{array}{c}\text { S-Ident } \\
\text { (voice) }\end{array}$ & $\begin{array}{l}\text { IDPWd-Ons } \\
\text { Stop (voice) }\end{array}$ & $\begin{array}{c}\text { PWd-Final } \\
\text { Devoicing }\end{array}$ \\
\hline a. & {$[(\mathrm{ra}: \mathrm{d}) .(\mathrm{za}: \mathrm{m})]$} & & & $* !$ \\
\hline b. & {$[(\mathrm{ra}: \mathrm{t}) .(\mathrm{za}: \mathrm{m})]$} & $* !$ & & $*$ \\
\hline c. & {$[(\mathrm{ra}: \mathrm{d}) .(\mathrm{sa}: \mathrm{m})]$} & $* !$ & & \\
\hline d. & {$[(\mathrm{ra}: \mathrm{t}) .(\mathrm{sa}: \mathrm{m})]$} & & & \\
\hline
\end{tabular}

The constraint ranking proposed here adequately accounts for all cases where two consonants are adjacent across a Prosodic Word boundary, i.e. when a stem and an external affix are involved $(61,62)$, in compounds $(63,64)$ and when a stem and a clitic are involved (65):

(62) <eetbaar> 'edible'

\begin{tabular}{|l|l|c:c|c|}
\hline & $\begin{array}{l}\text { Input: } \\
\text { le:t/ }+ \text { /ba:r/ }\end{array}$ & $\begin{array}{c}\text { S-Ident } \\
\text { (voice) }\end{array}$ & $\begin{array}{l}\text { IDPWd-Ons } \\
\text { Stop (voice) }\end{array}$ & $\begin{array}{c}\text { PWd-Final } \\
\text { Devoicing }\end{array}$ \\
\hline a. $*$ & {$[(\mathrm{e}: \mathrm{d}) .(\mathrm{ba}: \mathrm{r})]$} & & & $*$ \\
\hline b. & {$[(\mathrm{e}: \mathrm{t}) .(\mathrm{ba}: \mathrm{r})]$} & $* !$ & & \\
\hline c. & {$[(\mathrm{e}: \mathrm{d}) .(\mathrm{pa}: \mathrm{r})]$} & $* !$ & $*$ & $*$ \\
\hline d. & {$[$ (e:t).(pa:r)] } & & $* !$ & \\
\hline
\end{tabular}

(63) <slaapzak> 'sleeping bag'

\begin{tabular}{|l|l|c|l|c|}
\hline & $\begin{array}{l}\text { Input: } \\
\text { /sla:p/ + /zak/ }\end{array}$ & $\begin{array}{c}\text { S-Ident } \\
\text { (voice) }\end{array}$ & $\begin{array}{l}\text { IDPWd-Ons } \\
\text { Stop (voice) }\end{array}$ & $\begin{array}{c}\text { PWd-Final } \\
\text { Devoicing }\end{array}$ \\
\hline a. & {$[$ (sla:b).(zak)] } & & & $* !$ \\
\hline b. & {$[$ (sla:p).(zak)] } & $* !$ & & $*$ \\
\hline c. & {$[$ (sla:b).(sak)] } & $* !$ & & \\
\hline d. $*$ & {$[$ (sla:p).(sak)] } & & & $*$ \\
\hline
\end{tabular}


(64) <kasboek> 'cash-book'

\begin{tabular}{|l|l|c:c|c|}
\hline & $\begin{array}{l}\text { Input: } \\
\text { /kas/ + /buk/ }\end{array}$ & $\begin{array}{c}\text { S-Ident } \\
\text { (voice) }\end{array}$ & $\begin{array}{l}\text { IDPWd-Ons } \\
\text { Stop (voice) }\end{array}$ & $\begin{array}{c}\text { PWd-Final } \\
\text { Devoicing }\end{array}$ \\
\hline a. $*$ & {$[$ (kaz).(buk) $]$} & & & $*$ \\
\hline b. & {$[$ (kas).(buk)] } & $* !$ & & \\
\hline c. & {$[$ (kaz).(puk) $]$} & $* !$ & $*$ & $*$ \\
\hline d. & {$[$ (kas).(puk) $]$} & & $* !$ & \\
\hline
\end{tabular}

(65) <gaf-die> 'gave he'

\begin{tabular}{|l|l|c:c|c|}
\hline & $\begin{array}{l}\text { Input: } \\
/ \mathrm{xav} / \text { Stem }+/ \mathrm{di} /{ }_{\text {Clitic }}\end{array}$ & $\begin{array}{c}\text { S-Ident } \\
(\text { voice) }\end{array}$ & $\begin{array}{l}\text { IDPWd-Ons } \\
\text { Stop (voice) }\end{array}$ & $\begin{array}{c}\text { PWd-Final } \\
\text { Devoicing }\end{array}$ \\
\hline a. & {$[(\mathrm{xav})] . \mathrm{di}$} & & & $* !$ \\
\hline b. & {$[(\mathrm{xaf})] . \mathrm{di}$} & $* !$ & & $*$ \\
\hline c. & {$[(\mathrm{xav})] . \mathrm{ti}$} & $* !$ & & \\
\hline d. & {$[(\mathrm{xaf})] . \mathrm{ti}$} & & & \\
\hline
\end{tabular}

This constraint ranking explains cases where two consonants in a cluster are separated by a Prosodic Word boundary, but is not sufficient yet to give us the output forms in cases where two obstruents are adjacent within a Prosodic Word. This issue will be addressed now.

Our analysis crucially relies on the assumption that there are different locality requirements on the constraint that rules out voiced obstruents. PROSODIC WORD-FINAL DEVOICING rules out candidate (65a). In (66a), this constraint is vacuous. If the higherranked constraints S-IDENT (voice) and IDPWD-ONSET (voice) do not select an optimal output, the form with the least violations of lower-ranked constraints wins.

\begin{tabular}{|c|c|c|c|c|c|c|c|}
\hline (66) & $<$ leefde $>$ & 'live & & & & & \\
\hline & $\begin{array}{l}\text { Input: } \\
\text { /le:v/+ /də/ }\end{array}$ & $\begin{array}{l}\text { S-Ident } \\
\text { (voice) }\end{array}$ & $\begin{array}{c}\text { Syllable } \\
\text { Final } \\
\text { Devoicing }\end{array}$ & $\begin{array}{l}\text { IDent-Ons } \\
\text { (voice) }\end{array}$ & *Voice & $\begin{array}{c}\text { IDent } \\
\text { stop } \\
\text { (voice) }\end{array}$ & $\begin{array}{c}\text { IDent } \\
\text { (voice) }\end{array}$ \\
\hline a. $\$$ & [(le:v.də)] & & $*$ & & $* *$ & & \\
\hline b. & [(le:f.də)] & $* !$ & & & $*$ & & $*$ \\
\hline c. & [(le:v.tə)] & $* !$ & $*$ & $*$ & $*$ & $*$ & $*$ \\
\hline d. & [(le:f.tə)] & & & $*$ & & $*$ & $* * !$ \\
\hline
\end{tabular}

In this tableau, it is crucial that *VOICE is not ranked higher than IDENT (voice), otherwise (66a) would be less optimal than (66d). Without ranking *VOICE > IDENT (voice) and without the constraint Syllable Final DEVOICING, regular cases of final devoicing like in daadje [da:tjə] 'small deed' could not be accounted for. For this reason, 
the constraint Syllable Final Devoicing is introduced in the grammar that we propose.

\begin{tabular}{|c|c|c|c|c|c|c|c|}
\hline$(67)$ & $<$ daadje $>$ & 'small c & eed' & & & & \\
\hline & $\begin{array}{l}\text { Input: } \\
\text { /da:d/+/jə/ }\end{array}$ & $\begin{array}{c}\text { IDent PWd- } \\
\text { Ons Stop } \\
\text { (voice) }\end{array}$ & $\begin{array}{c}\text { Syllable Final } \\
\text { Devoicing }\end{array}$ & $\begin{array}{l}\text { IDent-Ons } \\
\text { (voice) }\end{array}$ & *Voice & $\begin{array}{l}\text { IDent } \\
\text { Stop } \\
\text { (voice) }\end{array}$ & $\begin{array}{l}\text { IDent } \\
\text { (voice) }\end{array}$ \\
\hline a. & [(da:d.jə)] & & $* !$ & & $* *$ & & \\
\hline b. & [(ta:d.jə)] & $* !$ & & $*$ & $*$ & $*$ & $*$ \\
\hline c. & {$[($ ta:t.jə)] } & $* !$ & & * & & $* *$ & $* *$ \\
\hline d. & [(da:t.jə)] & & & & $*$ & $*$ & $*$ \\
\hline
\end{tabular}

With Syllable FinAL DEVOICING we may now account for cases which are problematic in Lombardi's analysis, viz. cases that involve a stem plus a voiced obstruent initial internal affix. In (68) and (70), Syllable Final Devoicing is crucial. Without this constraint, the wrong candidate would be selected in (68), viz. candidate (68a), and we would not be able to decide between candidates (70a) and (70d).

\begin{tabular}{|c|c|c|c|c|c|c|c|}
\hline & $\begin{array}{l}\text { Input: } \\
\text { /klap/ + /də/ }\end{array}$ & $\begin{array}{l}\text { S-Ident } \\
\text { (voice) }\end{array}$ & $\begin{array}{c}\text { Syllable Final } \\
\text { Devoicing }\end{array}$ & $\begin{array}{l}\text { IDent-Ons } \\
\text { (voice) }\end{array}$ & *Voice & $\begin{array}{l}\text { IDent } \\
\text { stop } \\
\text { (voice) }\end{array}$ & $\begin{array}{l}\text { IDent } \\
\text { (voice) }\end{array}$ \\
\hline a. & [(klab.də)] & & $*$ & & $* *$ & $* !$ & $*$ \\
\hline b. & [(klap.də)] & $* !$ & & & $*$ & & \\
\hline c. & [(klab.tə)] & $* !$ & * & * & * & $* *$ & $* *$ \\
\hline d. & [(klap.tə)] & & & * & & $*$ & $*$ \\
\hline
\end{tabular}

(69) <tobde> 'drudged'

\begin{tabular}{|c|c|c|c|c|c|c|c|}
\hline & $\begin{array}{l}\text { Input: } \\
\text { /tob/+ /də/ }\end{array}$ & $\begin{array}{l}\text { S-Ident } \\
\text { (voice) }\end{array}$ & $\begin{array}{c}\text { Syllable Final } \\
\text { Devoicing }\end{array}$ & $\begin{array}{l}\text { IDent-Ons } \\
\text { (voice) }\end{array}$ & *Voice & $\begin{array}{c}\text { IDent } \\
\text { stop } \\
\text { (voice) }\end{array}$ & $\begin{array}{l}\text { IDent } \\
\text { (voice) }\end{array}$ \\
\hline a. & [(tob.də)] & & $*$ & & $* *$ & & \\
\hline b. & [(top.də)] & $* !$ & & & $*$ & $*$ & \\
\hline c. & [(tob.tə) $]$ & $* !$ & $*$ & $*$ & $*$ & $*$ & \\
\hline d. & [(təp.tə)] & & & $*$ & & $* *$ & $* ! *$ \\
\hline
\end{tabular}




\begin{tabular}{|c|c|c|c|c|c|c|c|}
\hline (70) & $<$ mafte $>$ & 'snoc & zed' & & & & \\
\hline & $\begin{array}{l}\text { Input: } \\
\text { /maf/+ /də/ }\end{array}$ & $\begin{array}{l}\text { S-Ident } \\
\text { (voice) }\end{array}$ & $\begin{array}{c}\text { Syllable Final } \\
\text { Devoicing }\end{array}$ & $\begin{array}{l}\text { IDent-Ons } \\
\text { (voice) }\end{array}$ & *Voice & $\begin{array}{l}\text { IDent } \\
\text { stop } \\
\text { (voice) }\end{array}$ & $\begin{array}{l}\text { IDent } \\
\text { (voice) }\end{array}$ \\
\hline a. & {$[(\mathrm{mav} \cdot \mathrm{d})]$} & & $*$ & & $* *$ & & $* !$ \\
\hline b. & [(maf.do)] & $* !$ & & & $*$ & & \\
\hline c. & {$[($ mav.to $)]$} & $* !$ & $*$ & $*$ & $*$ & $*$ & $* *$ \\
\hline d. & {$[$ (maf.tə)] } & & & $*$ & & $*$ & $*$ \\
\hline
\end{tabular}

In section 3, we accounted for resyllabification of stem-final obstruents before some suffixes and devoicing of stem-final obstruents before other suffixes and in compounds by assuming two different prosodic structures for the respective suffixes and a markedness constraint that is sensitive to Prosodic Word boundaries (31a, 60). The same prosodic structures and an identity constraint that is sensitive to Prosodic Word boundaries (see 59) help to explain why we find regressive voicing assimilation with one class of suffixes (i.e., the so-called 'external affixes' see 62) and progressive assimilation with others (i.e. the so-called 'internal affixes', see 68, 70).

The next issue to be addressed in this paper is the behaviour of clitics with respect devoicing of obstruents and voicing assimilation.

\section{The prosodic structure of clitics}

With respect to devoicing of stem-final obstruents, weak forms of personal pronouns (71b) differ from internal suffixes (71c), whereas they are similar to external suffixes (see 71d).
a. Ik gee/v/ haar een boek
[xe:f ha:r on buk]
'I give her a book'
b. Ik gee/v/'r een boek
[xe:f̧ror ən buk]
c. gee/v/ +- er $_{\text {Affix int }}$
[xe:vər]
d. die/v/ + -achtig Affix ext
[di:faxtəx]
'I give 'r a book'
'someone who gives'
'thievish'

We conclude from this that, unlike internal affixes, clitics that are weak forms of personal pronouns do not belong to the same Prosodic Word as the preceding morpheme. The question then arises whether clitics form a Prosodic Word of their own, or whether they are outside a Prosodic Word structure.

Booij (1995) points out that in Dutch, a Prosodic Word contains at least one full vowel. Moreover, a Prosodic Word may contain the reduced vowel /ə/, but it may not begin with Schwa: 
(72)
a. tel
[t $\varepsilon$ l]
'a second'
b. ebak
* [ə $\mathrm{b} \mathrm{a} \mathrm{k}$ ]
c. gebak
[x ə b a k]
'pastry, cake'
d. bakken
[b a k ə]
'to bake'

Since most clitics contain only a Schwa syllable (or even begin with a Schwa), these clitics cannot be Prosodic Words. This means that they differ from external suffixes that form a Prosodic Word of their own. In section 3, we followed Selkirk (1995) and analysed clitics as 'free' elements outside the Prosodic Word structure (cf. 40). This has consequences for stem-final consonants which are final in a Prosodic Word before Schwa-initial clitics, i.e. they are voiceless:

\begin{tabular}{|c|c|c|c|c|c|}
\hline (73) & /xe:v/ + /at/ & & e it' & & \\
\hline & $\begin{array}{l}\text { Input: } \\
\text { xe: } v_{\text {Stem }}+\partial t_{\text {Clitic }}\end{array}$ & $\begin{array}{l}\text { Align L } \\
\text { Stem }\end{array}$ & $\begin{array}{c}\text { Align R } \\
\text { PWd }\end{array}$ & $\begin{array}{l}\text { PWd-Final } \\
\text { Devoicing }\end{array}$ & Onset \\
\hline a. & {$[(\mathrm{xe}: \mathrm{v})] . \partial \mathrm{t}$} & & & $* !$ & * \\
\hline b. & [(xe:f)] .ot & & & & $*$ \\
\hline c. & {$[((x e:), v] \partial t)$} & & $* !$ & & \\
\hline d. & [(xe: . v] ət) & & $* !$ & & \\
\hline e. & {$[(\mathrm{xe}: \mathrm{f})] .(\mathrm{t})$} & & $* !$ & & $*$ \\
\hline
\end{tabular}

When a clitic begins with a voiced obstruent, the obstruent assimilates in voicing to a preceding consonant and this is accounted for by the constraint-ranking that we established in section 4.1:

\begin{tabular}{|c|c|c|c|c|}
\hline (74) & /xe:v/ + /zə/ & e> & 'give them' & \\
\hline & $\begin{array}{l}\text { Input: } \\
\text { xe: } \text { Stem }_{\text {St }}+\partial_{\text {Clitic }}\end{array}$ & $\begin{array}{l}\text { S-Ident } \\
\text { (voice) }\end{array}$ & $\begin{array}{l}\text { IDPWd-Ons } \\
\text { Stop (voice) }\end{array}$ & $\begin{array}{l}\text { PWd-Final } \\
\text { Devoicing }\end{array}$ \\
\hline a. & [ (xe:f)].zə & $* !$ & & \\
\hline b. & {$[(\mathrm{xe}: \mathrm{v})] . z \partial$} & & & *! \\
\hline c. & [ (xe:f)].sə & & & \\
\hline
\end{tabular}

Clitics may have lexical words as their host (see 73,74), or function words. Selkirk (1995) distinguishes between different prosodic structures for function words. Stressable function words may have the status of 'Prosodic Word', other function words may be incorporated into a Prosodic Word and still others are 'free' (i.e., they are not part of a Prosodic Word and they are directly adjoined to the Prosodic Phrase). The complementizer of 'whether' is stressed and we therefore assume that function words like of may be the head of a Prosodic Word: 
(75) of + die 'whether he'

\begin{tabular}{|l|l|c:l|c|}
\hline & $\begin{array}{l}\text { Input: } \\
\text { of }+\mathrm{di}_{\text {Clitic }}\end{array}$ & S-Ident & $\begin{array}{l}\text { IDPWd- Ons } \\
\text { Stop (voice) }\end{array}$ & $\begin{array}{c}\text { PWd-Final } \\
\text { Devoicing }\end{array}$ \\
\hline a. & (of).di & $* !$ & & \\
\hline b. & (ov).di & & & $* !$ \\
\hline c. $\%$ & (of).ti & & & \\
\hline
\end{tabular}

We furthermore propose that strong forms of personal pronouns are Prosodic Words (see 76a), but clitics such as 't, ze and die (weak forms of the $3^{\text {rd }}$ sg. neut., $3^{\text {rd }}$ pl., and $3^{\text {rd }}$ sg. masc. personal pronouns, respectively) are 'free' (see 76b):

(76)

a.

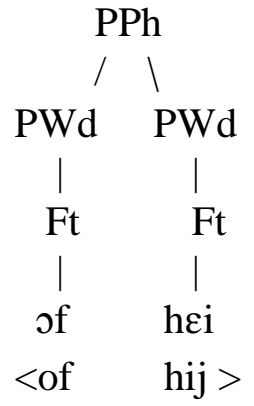

b.

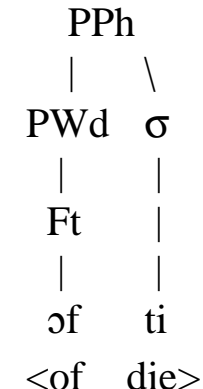

'whether he'

Clitics differ from external affixes which form a Prosodic Word of their own (see 77a) and from internal affixes which are inside the Prosodic Word (see 77b):

(77)

a.

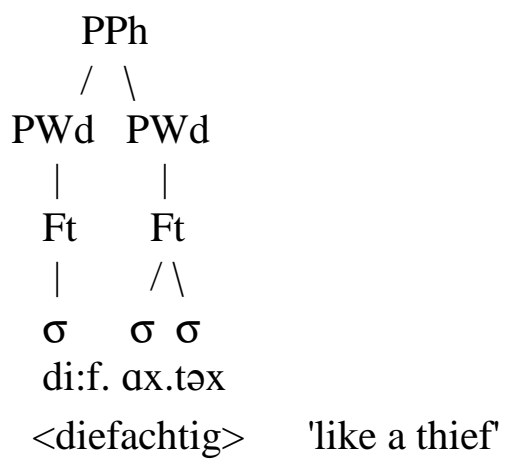

b. $\quad \mathrm{PPh}$

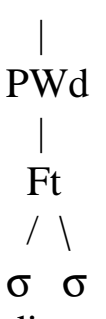

di:.vən

Final devoicing before clitics and voicing assimilation do not pose a problem for our analysis and can be accounted for with the same constraint rankings as for the ones proposed above for final-devoicing before external affixes (see section 3) and for voicing assimilation in the case of suffixes and compounds (see section 4). 


\subsection{Devoicing without 'sympathy'}

Forms like von.tik 'found I' used to pose a problem for analyses of Dutch, since in such forms, an underlying voiced plosive is devoiced in onset position. McCarthy (1998) proposed that the output candidate [von.t $k$ ] wins because it is sympathetic to a loosing candidate [vont] and being 'sympathetic' outranks being faithful to the input form /vond/. McCarthy bases himself on Booij $(1995,1996)$ who assumes that in the case of a stem plus a following vowel-initial clitic, the stem-final obstruent is devoiced at the lexical level. The stem-final obstruent is resyllabifies after the clitic is added at the postlexical level in order to avoid syllables without onsets:

\begin{tabular}{|c|c|c|c|c|c|}
\hline $\begin{array}{l}\text { Underl } \\
\text { Repres }\end{array}$ & & $\begin{array}{l}\text { Lexical Level } \\
\text { (devoicing) }\end{array}$ & $\begin{array}{l}\text { Postlexical } \\
\text { (resyllabific }\end{array}$ & $\begin{array}{l}\text { evel } \\
\text { tion) }\end{array}$ & \\
\hline a. /heb/ & $-->$ & $/ \mathrm{h} \varepsilon \mathrm{p} /$ & $+/ \mathrm{lk} / \quad-->$ & [he.pık] & 'have I' \\
\hline b. /xe:v/ & $-->$ & /xe:f/ & $+/ \partial t / \quad-->$ & [xe:.fət] & 'give it' \\
\hline c. /vond/ & $-->$ & /vont/ & $+/ \mathrm{lk} /$ & [von.tık] & 'found I' \\
\hline
\end{tabular}

In an informal investigation, ten native speakers were asked to repeat the third word that they heard embedded in a grammatical sentence (Petra zegt ... 'Petra says...' or Petra zegt ... een boek 'Petra says ... a book') and to syllabify this word in slow speech. The words in question were underived words and forms with clitics. Every person syllabified underived words with a long vowel with a syllable break after the vowel, whereas only one person syllabified the clitic form in this way (cf. 79a versus 80a). No speaker syllabified underived words with a short vowel with a syllable break after the intervocalic consonant, whereas eight speakers syllabified forms like heb'k 'have I' in this way.

\begin{tabular}{llllll}
\multicolumn{3}{c}{ Onset consonant } & \multicolumn{2}{l}{ Ambisyllabic } & \multicolumn{2}{l}{ Coda consonant } \\
a. ta:. fəl & $(100 \%)$ & ta:f.fəl & $(0 \%)$ & ta:f. əl ( 0\%) & 'table' \\
b. le. kər & $(60 \%)$ & lek.kər & $(40 \%)$ & lek. ər ( 0\%) & 'nice' \\
a. ge:.fər & $(10 \%)$ & ge:f.fər & $(0 \%)$ & ge:f.ər (90\%) & 'give her' \\
b. he.prk & $(10 \%)$ & hep.prk & $(10 \%)$ & hep.rk (80\%) & 'have I'
\end{tabular}

These findings do not support the claim made by Booij and others who postulate postlexical resyllabification in the case of clitics. Basing ourselves on the findings above, we assume that the supposed resyllabification in (78) does not take place. Forms like von.t Ik 'found I' used to pose a problem for analyses of Dutch. We defend the view that the actual output form is $(v o n t)_{\omega} . I k$. This form satisfies final devoicing and neither postlexical resyllabification nor "Sympathy" have to be postulated to explain the data. 


\subsection{Variation in voicing}

Ernestus (1997) found that in both frequent and non-frequent instances of a stem plus a clitic, a stem-final stop may be pronounced voiced or voiceless when followed by a vowel-initial clitic. Her findings do not show a preference for either pronunciation. In this regard, we note that for postverbal pronouns three possibilities are attested. The pronoun may be realised as a full pronominal form in which case we find stem-final devoicing (81a), or it can be a clitic in which case we also find stem-final devoicing (81b), or it may form a stronger unit with its host in which case we do not find stemfinal devoicing (81c):

(81) Different realisations of heb ik 'have I':
a. $h e p$ Ik
(two words)
b. hep Ik/hebək
$\left(\mathrm{X}^{0}\right.$ plus clitic)
c. hebok
$\left(\mathrm{X}^{0}\right.$ plus affix $)$

According to Selkirk (1995), function words can constitute independent Prosodic Words (see 76a, 81a), they can be 'free' and adjoined to a higher prosodic category (see the clitic in 76b, 81b), or they can be part of a Prosodic Word (81c). If Ernestus is right, we have to assume that weak forms of personal pronouns are sometimes considered to be 'free clitics' (as in 76b) and sometimes they are considered affixes (as in 77b).

\section{Conclusion}

Stem-final obstruents in Dutch behave differently in derivation, compounding, and cliticization. With respect to derivation, we have argued that one group of affixes are 'internal affixes' which do not form independent Prosodic Words, but form a Prosodic Word together with a preceding stem (e.g.,- $\partial r,-d \partial,-\partial x,-\partial l \partial k,-(t) j \partial)$. Another group of affixes are 'external affixes' which, like the members of compounds, form a Prosodic Word on their own. We have also argued that weak forms of personal pronouns are clitics that are not incorporated in a Prosodic Word and do not form a Prosodic Word of their own: 
(82)

a.

$\mathrm{PPh}$
$\mathrm{PWd}$
$\mid$
$\mathrm{FT}$
$\sigma \quad \sigma$
Stem Affix int
(ro: . dər)
<roder>
'redder'

$\mathrm{b}$

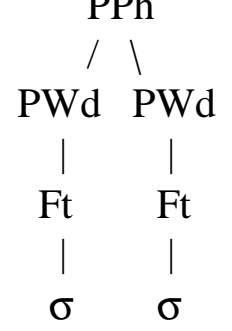

Stem Affix ext

(e:d) . (ba:r)

<eetbaar>

'edible' c. $\quad \mathrm{PPh}$

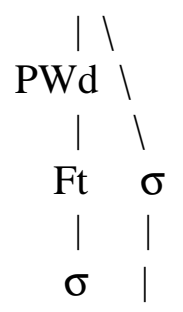

Stem Clitic

(ba:t) . or

$<$ baad 'r $>$

'bathe her'

Prosodic structure is not prespecified in the lexicon, but assigned by the grammar which contains constraints which align the edge of a stem or external affix with the edge of a Prosodic Word (see 38 and 35, respectively).

Final devoicing applies in all the cases where a stop or a fricative is the rightmost element of a Prosodic Word and where no voiced stop follows, as the following tables illustrate, respectively:

\begin{tabular}{l|l|l|l|l} 
(83) & $\begin{array}{c}\text { a. "internal } \\
\text { affixes" }\end{array}$ & $\begin{array}{l}\text { b. "external } \\
\text { affixes" }\end{array}$ & c. compounds & $\begin{array}{l}\text { d. "free } \\
\text { clitics" }\end{array}$ \\
\hline morphology & $\begin{array}{c}\text { stem + affix } \\
\text { ro:d + -ər }\end{array}$ & $\begin{array}{l}\text { stem + affix } \\
\text { ro:d + -axtəx }\end{array}$ & $\begin{array}{l}\text { stem + stem } \\
\text { hand + palm }\end{array}$ & $\begin{array}{l}\text { stem + clitic } \\
\text { ba:d + 'm }\end{array}$ \\
\hline prosody & (ro:.dər) & (ro:t).(axtəx) & (hant).(palm) & (ba:t).əm \\
\hline & 'redder' & 'red-like' & 'palm of hand' & 'bathe him'
\end{tabular}

\begin{tabular}{l|l|l|l|l} 
(84) & $\begin{array}{c}\text { a. "internal } \\
\text { affixes" }\end{array}$ & $\begin{array}{l}\text { b. "external } \\
\text { affixes" }\end{array}$ & c. compounds & $\begin{array}{l}\text { d. "free } \\
\text { clitics" }\end{array}$ \\
\hline morphology & $\begin{array}{l}\text { stem + affix } \\
\text { xe:v + -ər }\end{array}$ & $\begin{array}{l}\text { stem + affix } \\
\text { di:v + -axtəx }\end{array}$ & $\begin{array}{c}\text { stem + stem } \\
\text { li:v + heb }\end{array}$ & $\begin{array}{l}\text { stem + clitic } \\
\text { xe:v + 'r }\end{array}$ \\
\hline prosody & (xe:.vər) & (di:f).(axtəx) & (li:f).(hep) & (xe:f).ər \\
\hline & 'giver' & 'like a thief' & 'to love' & 'give her'
\end{tabular}

The two constraints (i) S-IDENT (voice) which says that two adjacent obstruents should agree in voicing and (ii) IDPWD ONSET STOP (voice) which says that a stop in onset position of a Prosodic Word should be faithful to its underlying specification for voicing are ranked higher than PWD-FINAL DEVOICING. This ranking results in the fact that final devoicing is sometimes made 'invisible'. If stem final obstruents are not final in the prosodic word $(83 \mathrm{a}, 84 \mathrm{a}, 85 \mathrm{a})$, or if they are followed by a voiced obstruent which is 
initial in a Prosodic Word $(85 \mathrm{~b}, \mathrm{c})$, final obstruents may be voiced. In all other instances they are voiceless.

\begin{tabular}{l|l|l|l|l} 
(85) & $\begin{array}{c}\text { a. "internal } \\
\text { affixes" }\end{array}$ & $\begin{array}{l}\text { b. "external } \\
\text { affixes" }\end{array}$ & c. compounds & $\begin{array}{l}\text { d. "free } \\
\text { clitics" }\end{array}$ \\
\hline morphology & $\begin{array}{l}\text { stem + affix } \\
\text { le:v + -də }\end{array}$ & $\begin{array}{l}\text { stem + affix } \\
\text { le:v + -ba:r }\end{array}$ & $\begin{array}{l}\text { stem + stem } \\
\text { stof + duk }\end{array}$ & $\begin{array}{l}\text { stem + clitic } \\
\text { xav + di }\end{array}$ \\
\hline prosody & (le:v.də) & (le:v).(ba:r) & (stov).(duk) & (xaf).ti \\
\hline & 'lived' & 'habitable' & 'duster' & 'gave he'
\end{tabular}

Final devoicing and voicing assimilation in Dutch are accounted for in a constraint-based framework with the help of three Alignment constraints (86a) which are ranked with respect to each other. Positional markedness constraints against voicing are ranked with respect to positional Identity (voice) constraints (86b):

a. Align L (Affix ext, PWd), Align L (Stem, PWd) $>$ Align R (PWd, Lex) > Onset

b. Surface Ident (voice), Ident PWd Onset Stop (voice) >> PWd-Final Devoicing, Syllable-Final Devoicing, Ident-Onset (voice) >> Ident Stop (voice), Ident (voice), *Voice

The analysis captures all the data that were problematic in a rule-based account. Furthermore, we have shown that in this analysis, no need arises to assume different levels (in the sense of Booij 1995 and Kiparsky 1998), or different 'co-phonologies' in one language (Inkelas 1994b), and neither do we have to assume 'Sympathy' (in the sense of McCarthy 1998) to explain the Dutch data.

\section{References}

Beckman, Jill N., Laura Walsh Dickey \& Suzanne Urbanczyk (1995), University of Massachusetts Occasional Papers 18: Papers in Optimality Theory, Amherst: GLSA, University of Massachusetts, Amherst.

Benua, Laura (1995), "Identity Effects in Morphological Truncation", in Beckman, J.N. et al (1995): 77-136.

Berendsen, Egon (1983), "Final devoicing, assimilation, and subject clitics in Dutch", in Hans Bennis \& W.U.S, van Lessen Kloeke (eds.), Linguistics in the Netherlands. Dordrecht: Foris: 21-29.

Berendsen, Egon, Ellis Visch \& Wim Zonneveld (1984), Generatieve Fonologie en de Linkerkant van de Grammatika, Den Haag: Nijhoff.

Booij, Geert (1995), The Phonology of Dutch, Oxford: Clarendon Press.

Booij, Geert (1996), "Cliticization as prosodic integration: the case of Dutch", in Linguistic Review, 13: 219-242.

Butska, Luba (1998), "Faithfulness and Voicing Alternations in Ukranian", Ms, Rutgers University. 
Ernestus, Mirjam T. C. (1997), "The Voicedness of Intervocalic Word-Final Stops in Dutch", in Jane Coerts \& Helen de Hoop (eds.) Linguistics in the Netherlands. Amsterdam/Philadelphia: John Benjamins: 73-84.

Hulst, Harry van der (1985), "Ambisyllabicity in Dutch", in Hans Bennis \& Frits Beukema (eds.) Linguistics in the Netherlands. Dordrecht: Foris Publications: 57-66.

Inkelas, Sharon (1994a), "The Consequences of Optimization for Underspecification", in NELS 25:287-302.

Inkelas, Sharon (1994b), "Exceptional stress-attracting suffixes in Turkish: representations vs. the grammar", Ms., to appear in R. Kager, H. van der Hulst \& W. Zonneveld (eds), The Prosody Morphology Interface, Cambridge University Press.

Itô, Junko \& Armin Mester (1994), "Reflections on CodaCond and Alignment", in Jason Merchant, Jaye Padgett \& Rachel Walker (eds), Phonology at Santa Cruz, Vol. 3:27-46.

Kager, René (1996), "Stem Stress and Peak Correspondence in Dutch", Ms., Utrecht University, to appear in J. Dekkers et al (eds.), Optimality Theory: phonology, syntax, and acquisition, Oxford: Oxford University Press.

Kiparsky, Paul (1998), "Paradigm effects and opacity", Ms., Stanford University.

Krämer, Martin (1998), "A Correspondence Approach to Vowel Harmony and Disharmony", in Theorie des Lexikons: Arbeiten des Sonderforschungsbereich 282, Nr. 107, BUGH Wuppertal and Heinrich-Heine-Universität, Düsseldorf (also available as ROA 2930199).

Krämer, Martin (1999), "Voicing Alternations and Underlying Representations: A Comparison of Breton and Dutch", Ms,, Heinrich-Heine-Universität, Düsseldorf.

Lombardi, Linda (1995), "Laryngeal neutralization and alignment", in Beckman, J.N. et al (1995): 225-47.

Lombardi, Linda (1996), "Restrictions on direction of voicing assimilation: an OT account", in University of Maryland Working Papers in Linguistics 3: 89-115.

McCarthy, John (1998), "Sympathy \& Phonological Opacity", Ms., University of Massachusetts, Amherst.

McCarthy, John \& Alan Prince (1993), "Generalized Alignment", in Yearbook of Morphology 1993, Dordrecht: Kluwer: 79-153.

McCarthy, John \& Alan Prince (1995), "Faithfulness and reduplicative identity", in Beckman J.N. et al (1995): 249-384.

Nespor, Marina \& Irene Vogel (1986), Prosodic Phonology, Dordrecht: Foris.

Prince, Alan \& Paul Smolensky (1993), "Optimality Theory: Constraint Interaction in Generative Grammar", Ms., Technical Report \# 2 of the Rutgers Center for Cognitive Science, Rutgers University.

Selkirk, Elisabeth (1995), "The Prosodic Structure of Function Words", in Beckman, J.N. et al (1995): 439-470.

Smolensky, Paul (1993), Harmony, markedness, and phonological activity. Paper presented at Rutgers Optimality Workshop-1 at Rutgers University: New Brunswick, NJ, October 1993.

Smolensky, Paul (1995), On the internal structure of the constraint component of UG. Colloquium presented at University of California: Los Angeles, April 7, 1995.

Trommelen, Mieke \& Wim Zonneveld (1989), Klemtoon en metrische fonologie, Muiderberg: Coutinho.

Zonneveld, Wim (1983), "Lexical and Phonological Properties of Dutch Voicing Assimilation", in Marcel van den Broecke, Vincent van Heuven \& Wim Zonneveld (eds.), Studies for Antonie Cohen: Sound Structures. Dordrecht: Foris: 297-312. 


\section{Appendix}

(87) So-called "internal suffixes" are part of the Prosodic Word:

\begin{tabular}{|l|l|c:c|c|c|}
\hline & $\begin{array}{l}\text { Input: } \\
\text { xe: }\end{array}$ Stem + ər $_{\text {Affix int }}$ & $\begin{array}{c}\text { PWd-final } \\
\text { devoicing }\end{array}$ & $\begin{array}{c}\text { Align L } \\
\text { Stem }\end{array}$ & $\begin{array}{c}\text { Align R } \\
\text { PWd }\end{array}$ & Onset \\
\hline a. & (xe:v) .ər & $* !$ & & $*$ & $*$ \\
\hline b. & (xe:f) .ər & & & $* !$ & $*$ \\
\hline c. & (xe:). vər & & & $* !$ & \\
\hline d. & ((xe:). vər) & & & $* !$ & \\
\hline e. & (xe: . vər) & & & & \\
\hline f. & (xe:f . ər) & & & & $* !$ \\
\hline g. & (xe:f).(วr) & & & $* !$ & $*$ \\
\hline
\end{tabular}

(88) So-called "external suffixes" form an independent Prosodic Word:

\begin{tabular}{|c|c|c|c|c|c|}
\hline & $\begin{array}{l}\text { Input: } \\
\text { div }_{\text {Stem }}+\operatorname{axt}_{\text {Aff ext }}\end{array}$ & $\begin{array}{l}\text { PWd-final } \\
\text { devoicing }\end{array}$ & $\begin{array}{l}\text { Align L } \\
\text { Affix ext }\end{array}$ & $\begin{array}{l}\text { Align R } \\
\text { PWd }\end{array}$ & Onset \\
\hline a. & (div) . ax.tox & $* !$ & $*$ & $*$ & $*$ \\
\hline b. & (dif) . ax.təx & & $* !$ & $*$ & $*$ \\
\hline c. & (di).(vax.təx) & & $* !$ & $*$ & \\
\hline d. & ((di) . vax.tox) & & $* !$ & $*$ & \\
\hline e. & (di. vax.təx) & & $* !$ & & \\
\hline f. & (dif .ax.təx) & & $* !$ & & $*$ \\
\hline g. & (div).(ax.təx) & $* !$ & & $*$ & $*$ \\
\hline h. & (dif).(ax.tox) & & & $*$ & $*$ \\
\hline
\end{tabular}

(89) External and internal affixes:

\begin{tabular}{|c|c|c|c|c|c|}
\hline & $\begin{array}{ll}\text { Input: } & \text { ro: } \\
\text { axt }_{\text {Stem }}+\end{array}$ & $\begin{array}{l}\text { PWd-final } \\
\text { devoicing }\end{array}$ & $\begin{array}{l}\text { Align L } \\
\text { Affix }_{\text {ext }}\end{array}$ & $\begin{array}{l}\text { Align R } \\
\text { PWd }\end{array}$ & Onset \\
\hline a. & (ro:d) . ax.təx . or & $* !$ & $*$ & $*$ & $* *$ \\
\hline b. & (ro:t) . ax.təx . ər & & $* !$ & * & *** \\
\hline c. & $(r o: t) \cdot(a x . t \partial x) . \partial r$ & & & $* * !$ & ** \\
\hline d. & (ro:t) . (ax.tə) . xər & & & $* * !$ & $*$ \\
\hline e. & (ro:t) . (ax.təx. ər) & & & * & $* * !$ \\
\hline f. & (ro:t) . (ax.tə.xər) & & & $*$ & * \\
\hline
\end{tabular}

(90) Clitics are not part of a Prosodic Word and do not form a Prosodic Word:

\begin{tabular}{|c|c|c|c|c|}
\hline & $\begin{array}{l}\text { Input: } \\
\text { xe: } v_{\text {Stem }}+\partial r_{\text {Clitic }}\end{array}$ & $\begin{array}{l}\text { PWd-final } \\
\text { devoicing }\end{array}$ & $\begin{array}{l}\text { Align R } \\
\text { PWd }\end{array}$ & Onset \\
\hline a. & [(xe:v)] .or & $* !$ & & * \\
\hline b. & [(xe:f)] .ər & & & * \\
\hline c. & {$[(\mathrm{xe}:) . \mathrm{v}]$ or } & & $* !$ & \\
\hline $\mathrm{d}$. & [(xe: . v] or) & & $* !$ & \\
\hline e. & [ (xe:f] . or) & & $* !$ & * \\
\hline f. & [(xe:v)].(วr) & $* !$ & $*$ & * \\
\hline g. & [(xe:f)].(or) & & $* !$ & * \\
\hline
\end{tabular}

